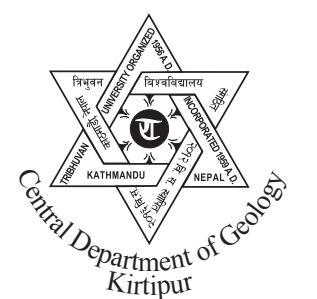

\title{
Morpho-hydrologic parameters and classification of the Kodku River for stream stability assessment, southern Kathmandu, Central Nepal
}

\author{
*Naresh Kazi Tamrakar, Ramita Bajracharya, Ishwor Thapa, \\ Sudarshon Sapkota and Prem Nath Paudel \\ Central Department of Geology, Tribhuvan University, Kathmandu, Nepal
}

\begin{abstract}
The Kodku River Corridor is one of the most potential corridors for future development of roads that would link the southern remote areas of the Kathmandu Valley to the inner core areas. River stability is of great concern as the unstable segment of river may pose threat on infrastructures, and adjacent cultivated lands and settlement areas. In this light, the preliminary assessment of the Kodku River as a part of the stability assessment was undertaken. The broad level geomorphic and hydrologic parameters, and Level I and II classifications of the river were made to assess for stability condition.

The Kodku River is a fifth order stream, extending for about $15.86 \mathrm{~km}$ and its watershed covering an area of $35.67 \mathrm{sq} . \mathrm{km}$. The relative relief is extremely high to low, and diminishes with change of landforms from steep terrain in the southern part to the gentle sloped terraces in the northern part of the watershed. Drainage texture is fine to very coarse, from the southern to the norther parts of the watershed. All the stream segments are sinuous $(K=1.2)$ whereas the Arubot Segment is the highly meandering (1.7). Both meander wavelength and belt width increase with increasing stream order. Five types of valleys have been distinguished; I, II, IV, VI, and VIII type valleys. Based on valley type distribution, channel pattern, shape and channel slope, the stream segments have been classified using Level I assessment as 'B' type, 'C' type and 'Aa+' type streams. The ' $B$ ' type streams are all located in the third order segment. Except the 'Aa+' type stream, all the fifth and fourth order stream segments belong to ' $\mathrm{C}$ ' type streams. Width/Depth ratio varying between 10.5 and 29.5 indicates laterally unstable channel segments. The bank height ratio, which varies between 1.6 and 2.4, indicates moderate incision and shows vertical instability of streams. The Badikhel Segment is relatively more entrenched (1.7) while the Taukhel Segment is the least entrenched (7.1). Since Entrenchment Ratio exceeds 1.6, the stream segments are considered to have moderate to low entrenchment. Based on the bed material load, the Kodku River is a gravelly mixed-load river, in which pebbles to silt/clay occur. Level II classification distinguishes three-types of streams; 'B4c" type (Badikhel Segment), 'C6c' type (Taukhel Segment), and 'C4c" type (Arubot, Thaiba and Harisidhi Segments). The 'B4c' type stream has tendency of vertical instability. The 'C6c" and 'C4c" type streams have shallow and wide meandering channels with well developed flood plains and lateral bars, and reflect tendency of lateral instability.
\end{abstract}

Key words: River stability, hydrology, river morphology, meander wavelength, river classification

Submitted: 8 June, 2013

Accepted: 5 Aug, 2013

\section{INTRODUCTION}

The Kodku River is one of the major tributaries of the Manahara River, contributing from the southern part of the Kathmandu basin (Fig. 1). It has a typical source

\footnotetext{
*Corresponding author:

E-mail address: ntamrakar@hotmail.com
}

of metasedimentary terrain composing dominantly of limestone of the Phulchoki Group (Stöcklin, 1980). The upliftment of the southern ranges of the Kathmandu basin (Saijo et al., 1995; Yagi et al., 2000) has been sheding sediments as carried by the southern rivers. These gravel to clayey sediments have been deposited as valley fill sediments, both basin marginal and central, and have 


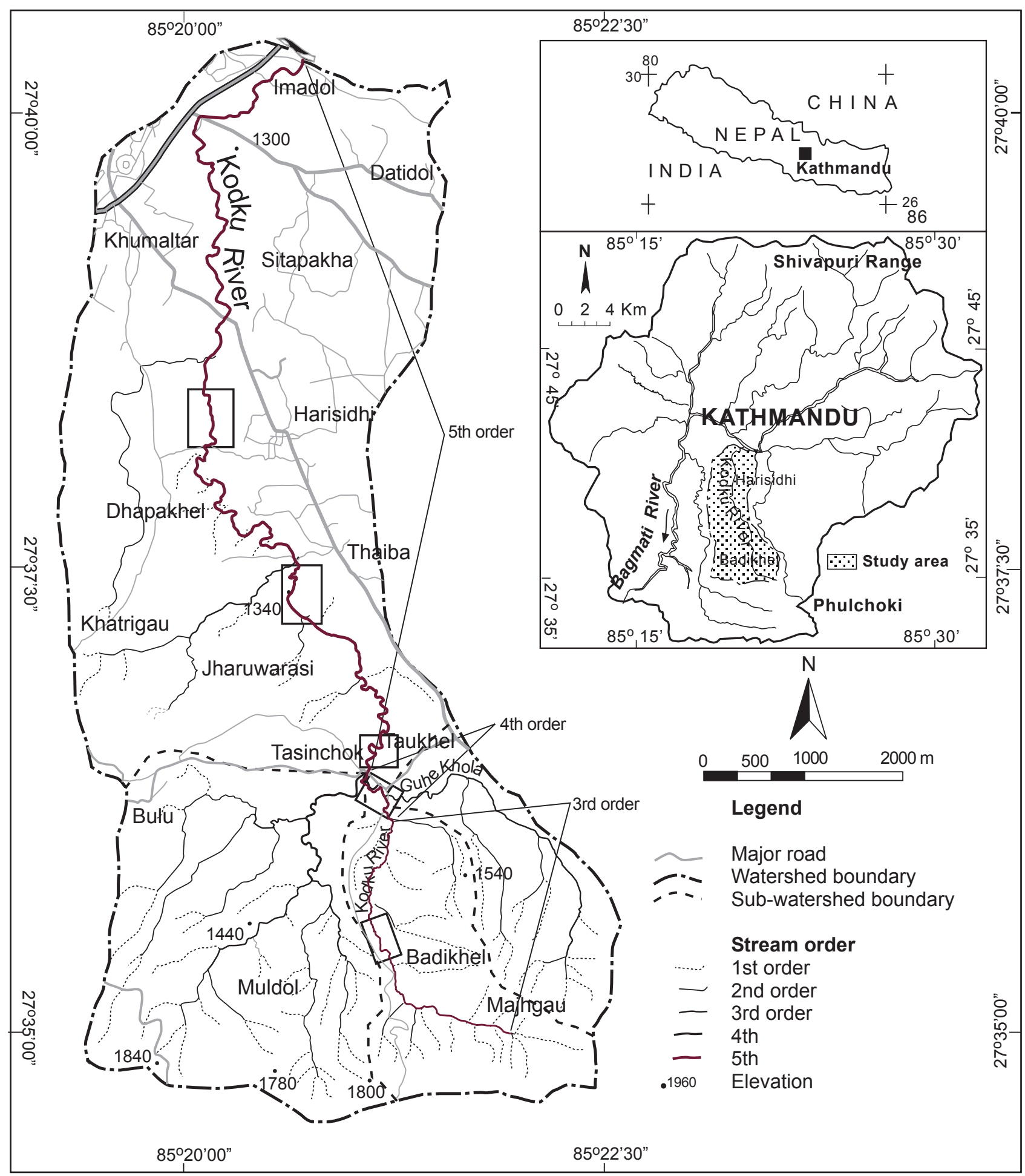

Fig. 1 Location map, drainage order and four surveyed segments of the Kodku River

been classified by various earlier workers (Yoshida and Igarashi, 1984; DMG, 1998; Sakai, H., 2001). Therefore, the Kodku River watershed has its southern portion characterized by bedrocks, colluvium and terrace deposits, while the northern portion by fluvio-lacustrine deposits.

The Kodku Rivers is of fifth order with sinuous pattern. It has wide floodplains with narrow channel belt. 
Urbanization in both the Kodku Rivers is very rapid at present. Many civil colonies have been erected and roads have been extended to facilitate transportation. In this circumstance of growing trend of urbanization, the rivers have been notably disturbed and instead the rivers have become threats to the settlement area, as they may unexpectedly flood and inundate the floodplains. There were many flash flooding taking place in the Kodku River. In 1979 Dhapakhel area was flooded, while in 1981, 2002 and 2007, Imadol and Gwarko areas were flooded and damaged partially. In 2002 Gwarko area was inundated for more than a week. More recently the lower reach of the Nakhu River (Maharjan and Tamrakar, 2010) has been very much disturbed by various anthropogenic factors, which have altered and impaired stability condition and function of the river. Riverbank erosion is an important cause of lateral erosion of toe of the slope and in generating slope movements (Shrestha and Tamrakar, 2007; Shrestha et al. 2008; Tamrakar et al. 2007). Therefore, river bank erosion poses threat on the infrastructures. In other words, the stream channel stability should be well assessed to know channel stability condition of the river before establishing infrastructures and developing the river corridor as settlement areas. Tamrakar (2004), Shrestha and Tamrakar (2007), Tamrakar and Bajracharya (2009) evaluated stability condition of the Bishnumati and the Manahara Rivers, the major tributaries of the Bagmati River originating from the northern ranges. Shrestha and Tamrakar (2011) evaluated disturbances in the Bagmati River. Tamrakar and Bajracharya (2012) worked out the watershed scale parameters of the Kodku and the Godavari Rivers.

Study of the Kodku River by Maharjan and Dangol (2007) for engineering hydrology suggests that this river is appreciable for drinking water source for Lalitpur city. But currently, the downstream segments of this river is suffering from channel encroachment and disposal of industrial and municipal wastes, and thus, anthropogenic activities are very influencial in environmental degradation of the river.

Secondly, the Kodku River Corridor is one of the most potential corridors for future development of roads which would link the southern remote areas of the Kathmandu Valley to the inner core areas. Transportation facility makes ease of people welfare, and helps to grow agricultural, industrial, and trading sectors. Extension of highways and roads are associated with establishment of number of large engineering structures (bridge, tunnel, stabilization and retaining structures). In other words, there will be involved huge investment for these structures during the extension of highway. Therefore, the objectives of this study are to document morpholigica and hydrologic parameters, and to categorize the stream segments in to the classification schemes of initial levels.

The Kodku River watershed is located in the southern part of the Kathmandu valley (Fig.1). The watershed area of this river lies in the Lalitpur district. It extends for about $15.86 \mathrm{~km}$ and covers an area of $35.67 \mathrm{sq} . \mathrm{km}$. The altitude ranges from $1960 \mathrm{~m}$ to $1290 \mathrm{~m}$. It originates from the north facing Tileswor Dada and Chaughare Dada located on southern part of the Kathmandu Valley. The watershed area is demarcated by the basement rocks of the Phulchwocki Group in the southern part, while by the Pleistoscene to Pliocene deposits of valley sediments in the other part. In the west the Nakhu River watershed lies whereas in the east the Godavari River watershed locates.

\section{METHODOLOGY}

The regional watershed parameters \& river planiform were measured from the topo maps $(1: 10,000$ and $1: 25,000) \&$ reconnaissance field visit was made along the river. The river inventory hierarchy set up by Rosgen (1996) was adopted. This would allow an assessment at various levels appropriate to the level of inquiry. In this study the initial levels, i.e., Level I and Level II classifications were made. In Level I, geomorphic parameters, which were determined were channel slope, channel shape, channel pattern, stream order, and spatial distribution of drainage network and relief, and general distribution of main stream types from A through G.

In Level II Morpho-hydrologic description involved sinuosity (K), Entrenchment Ratio (ER), Width/Depth ratio, Meander Width Ratio (MWR), channel slope, channel material, etc. For achieving these, five representative segments of the Kodku River were selected based on their planiform, and nature of channel condition, as Badikhel segment (3rd order), Taukhel segment (4th order), Arubot segment (5th order), Thaiba segment (5th order) and Harisidhi segment (5th order) (Fig. 1). These segments were surveyed for cross-sectional and 
longitudinal profiles using a leveling instrument, staff and a measuring tape. For the characterisation of grain size in segment, Wolman's (1954) pebble counting method was applied in each of the transects of individual segment. The median grain size obtained from segment counting was applied in stream classification after Rogen(1994). The stream segments were classified according to the Level II criteria of Rosgen (1994).

\section{WATERSHED-SCALE PARAMETERS}

Level I inventrogy of stream stability assessment includes all the broad watershed-scale parameters that incorporate landuse, relative relief, drainage texture, stream order and geology. For determination of these parameters, the spatial aspects of the whole watershed are considered.

\section{Landuse}

Most of the floodplains, the low-lying land and the gentle slope area are used for farming and settlement. The other parts are covered by forest, and some of the parts as quarry sites for brick industries. Most of the southern parts of watershed consist of steep to gentle slopes, which are covered by forest. Most of the quarries lie south of Thaba where extensive fluvio-lacustrine sediments lie.

With demand for settlement for growing population, the landuse pattern has changed rapidly in the watershed. Most of the huge floodplains of the Kodku River from downstream of Thaiba, i.e., the northern half portion of the watershed, has been used for build-up area, farm land and industrial area. The water quality has also been highly degraded due to contamination of sewer and solid waste disposed to the lower portion of the Kodku River lying north of Harisidhi.

\section{Relative relief}

Relative relief (RR), which is defined as the difference in height between the highest and the lowest points on the grid of a square kilometer, ranges from extremely high to low (Fig. 2). It is extremely high in Majhgau and Badikhel, high in Muldol area, and moderate to moderately low in Taukhel Dhapakhel, Harisidhi and Khumaltar. It is low in Imadol area. Relative relief diminishes from the south to the north of the watershed.

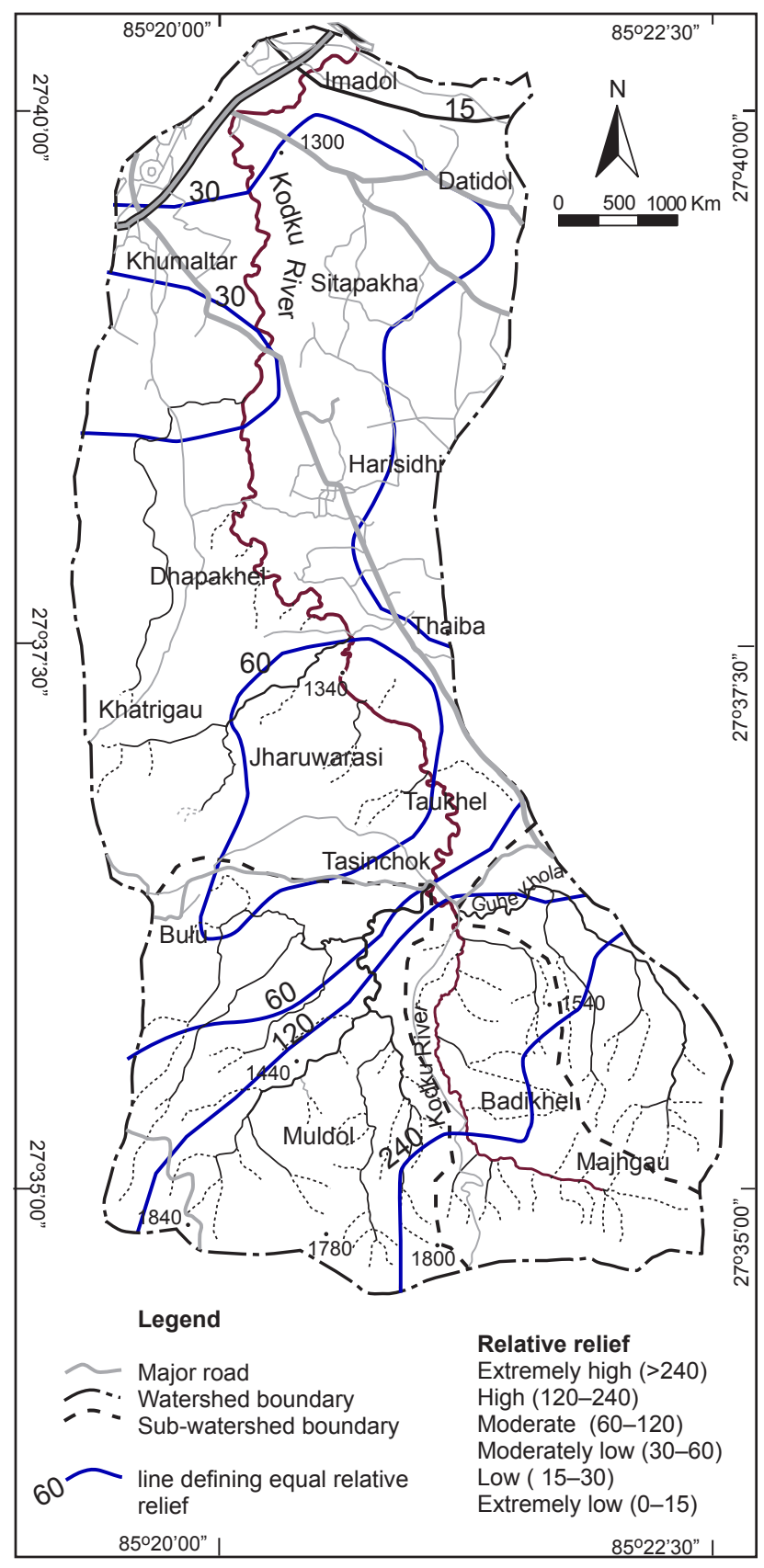

Fig. 2 A map showing relative relief in the Kodkhu watershed.

\section{Drainage texture}

The drainage texture (DT) is defined as the number of stream segment passes across per unit length within the square grid area (Horton, 1945). The Kodku River basin has drainage texture that ranges from fine to very coarse (Fig. 3). It is fine in the southern mountain area such as Badikhel, moderate in Majhgau and Muldol, coarse in Bulu and Khatrigau, and very coarse in 
Morpho-hydrologic parameters and classification of the Kodku River for stream stability assessment, southern Kathmandu, Central Nepal

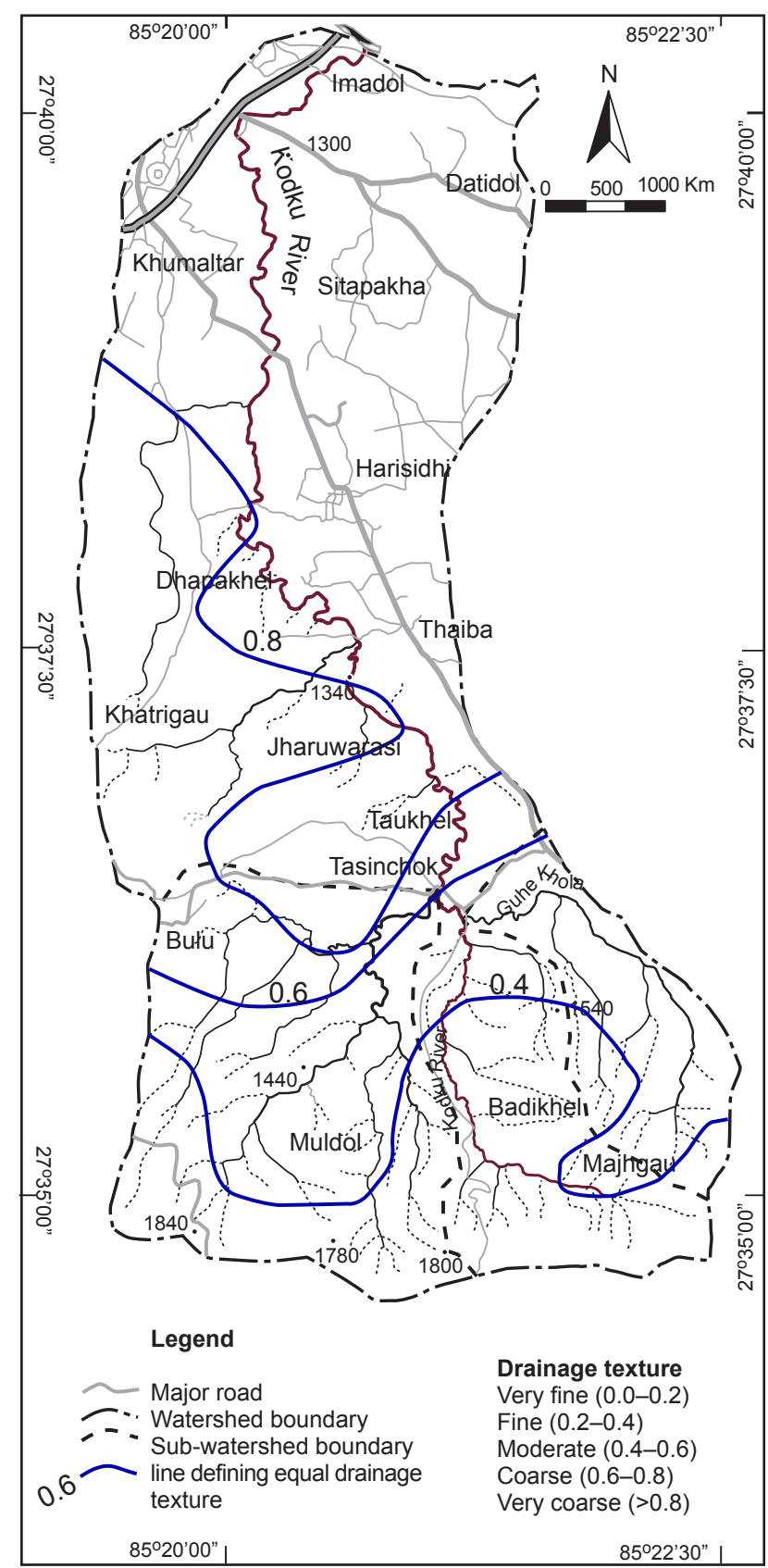

Fig. 3 A map showing drainage texture in the Kodkhu watershed.

Taukhel, Harisidhi, Khumaltar and Imadol. Areas with bedrocks and relatively high relief constitute relatively fine drainage texture. Drainage texture is controlled by distribution of bedrocks and soft sediments.

\section{Stream order}

Stream ordering refers to the determination of the hierarchical position of a stream within a drainage basin. Stream order is defined as 'a measure of the position of
Table 1: River morphological data of the Kodku River

\begin{tabular}{llccc}
\hline \multicolumn{1}{c}{ Parameters } & & \multicolumn{3}{c}{ Stream order } \\
\cline { 3 - 5 } & & Third & Fourth & Fifth \\
\hline Meander wavelength & $\mathrm{L}_{\mathrm{m}}, \mathrm{m}$ & 95 & 95.7 & 161.2 \\
Meander belt width & $\mathrm{W}_{\text {blt }}, \mathrm{m}$ & 56.3 & 67.2 & 223.1 \\
Radius of curvature & $\mathrm{R}_{\mathrm{c}}, \mathrm{m}$ & 35.5 & 28.3 & 53.3 \\
Length of thalweg & $\mathrm{L}_{\text {Thalweg }}, \mathrm{m}$ & 3440 & 793 & 11886 \\
Length of valley & $\mathrm{L}_{\text {Valley }}, \mathrm{m}$ & 3046 & 614 & 8736 \\
Sinuosity & $\mathrm{K}$ & 1.13 & 1.29 & 1.36 \\
\hline
\end{tabular}

*Sinuosity (K): Sinuous (1.05 to 1.5$)$; Straight $(<1.05)$ based on Leopold and Wolman (1957)

a stream in the hierarchy of tributaries' (Leopold, Wolman and Miller, 1964). In this study, the drainage order was determined using the method proposed by Strahler (1957, 1969). The Kodku Watershed constitutes three subwatersheds, of which the elongate Kodku sub-watershed is contributed by the Guhe sub-watershed from the east and the sub-watershed (Muldol area) from the southwest. The Kodku mainstem River is the fifth order river (Fig. 4). There are altogether twenty-two 2nd-order, six 3rdorder and two 4 th-order streams in the watershed. The third order main stem stretches for about $3440 \mathrm{~m}$ from Majhgau up to the confluence of the Kodku River with the Guhe Khola (Fig. 4; Table 1). The fourth order main stem river stretches for $793 \mathrm{~m}$ up to Tasinchok where it confluences with the major tributaries extending from the Muldol sub-watershed. The fifth order main stem river stretches for about $11886 \mathrm{~m}$ and finally contributes the Manahara River.

\section{Planform}

The planform geometry is well attributed by various parameters: sinuosity $(\mathrm{K})$, meander wavelength $\left(\mathrm{L}_{\mathrm{m}}\right)$, meander belt width $\left(\mathrm{W}_{\mathrm{blt}}\right)$, and radius of curvature $\left(\mathrm{R}_{\mathrm{c}}\right)$. Sinuosity is the ratio of stream channel length to downvalley distance. Meander wavelength $\left(\mathrm{L}_{\mathrm{m}}\right)$ of the river is the distance between two successive crests or two successive trough of the curved channel. Meander belt width $\left(\mathrm{W}_{\mathrm{blt}}\right)$ is a straight line between the crest of the bend to the crest of the next bend lying downstream, or is the distance between lines defining the confinement of the lateral boundaries of the channel. Radius of curvature $\left(R_{c}\right)$ is the radius of a circle drown through the apex of the bend and the two crossover midpoint of river, and is defined as the curved surface formed by the meandering stream channel. All these parameters were 


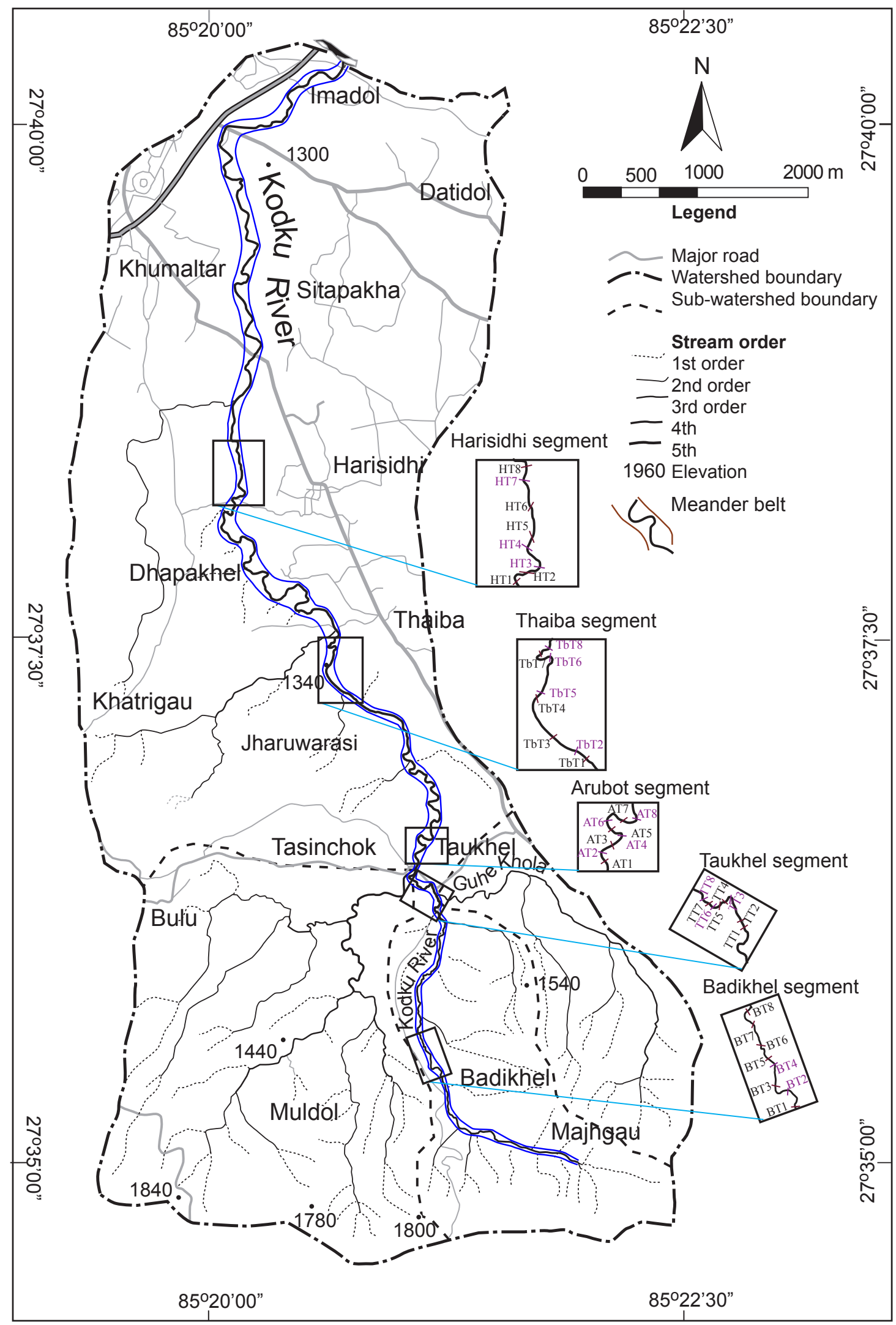

Fig. 4 A map of the Kodku watershed showing meander belt, segments and transect lines. 
Table 2: Planiform parameters of the Kodku River

\begin{tabular}{lccccc}
\hline & $\begin{array}{c}\text { Badikhel } \\
\text { Segment }\end{array}$ & $\begin{array}{c}\text { Taukhel } \\
\text { Segment }\end{array}$ & $\begin{array}{c}\text { Arubot } \\
\text { Segment }\end{array}$ & $\begin{array}{c}\text { Thaiba } \\
\text { Segment }\end{array}$ & $\begin{array}{c}\text { Harisidhi } \\
\text { Segment }\end{array}$ \\
\hline Planiform Parameters & & & & & \\
Length of thalweg, $\mathrm{L}_{\mathrm{tw}}(\mathrm{m})$ & 523.2 & 580.2 & 714.8 & 779.6 & 569.8 \\
Length of valley, $\mathrm{L}_{\text {valley }}(\mathrm{m})$ & 419.6 & 450.7 & 419.6 & 650.1 & 486.9 \\
Sinuosity, $\mathrm{K}=\mathrm{L}_{\mathrm{tw}} / \mathrm{L}_{\mathrm{valley}}$ & 1.2 & 1.3 & 1.7 & 1.2 & 1.2 \\
Meander wavelength, $\mathrm{L}_{\mathrm{m}}(\mathrm{m})$ & 75.9 & 97.4 & 140.0 & 147.8 & 105.2 \\
Meander belt width, $\mathrm{W}_{\mathrm{blt}}(\mathrm{m})$ & 57.4 & 71.9 & 96.2 & 99.5 & 92.7 \\
Radius of curvature, $\mathrm{R}_{\mathrm{c}}(\mathrm{m})$ & 24.7 & 27.5 & 36.8 & 72.8 & 34.9 \\
Meander length ratio, $\mathrm{MLR}=\mathrm{L}_{\mathrm{m}} / \mathrm{W}_{\mathrm{bkf}}$ & 9.6 & 16.8 & 17.3 & 18.5 & 6.9 \\
Meander belt ratio, $\mathrm{MBR}=\mathrm{W}_{\mathrm{blt}} / \mathrm{W}_{\mathrm{bkf}}$ & 7.3 & 12.4 & 11.9 & 12.4 & 6.1 \\
\hline
\end{tabular}

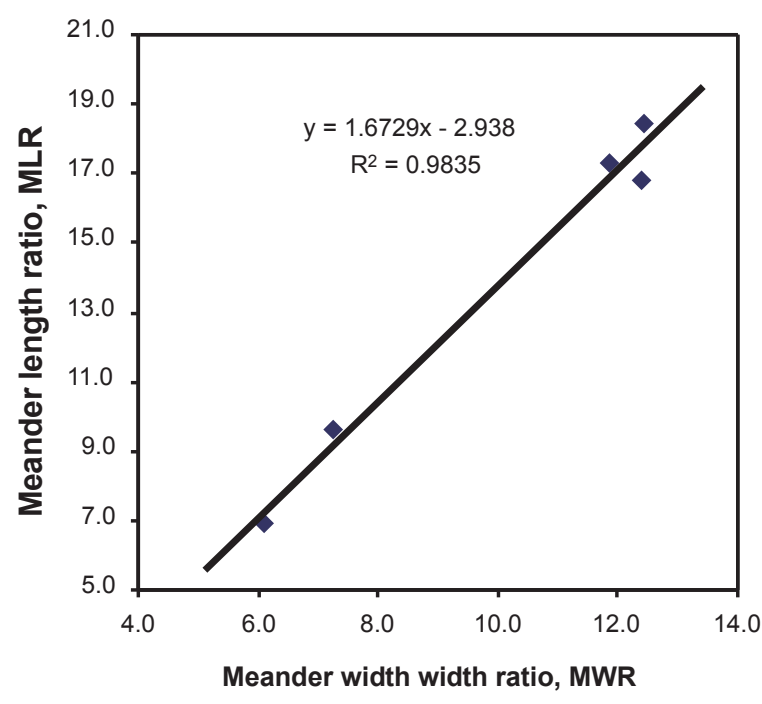

Fig. 5 Relationship between meander length ratio and meander width ratio.

calculated from the topographic map enlarge to 1:10,000scale.

The results of planform parameters calculated for 3rd to 5 th order stream streches (Fig. 4) are listed in Table 1. Sinuosity indices of the third, fourth and fifth order main stem stretches of the Kodku River are 1.13, 1.29, and 1.36, respectively showing sinuous nature according to classification of Leopold and Wolman (1957). The Meander wavelength, belt width and radius of curvature of the fifth order main stem river are $161.2 \mathrm{~m}, 223.1 \mathrm{~m}$, and $53.3 \mathrm{~m}$, respectively. Both $\mathrm{L}_{\mathrm{m}}$ and $\mathrm{W}_{\text {blt }}$ gradually increase from the $3 \mathrm{rd}$ to the 4 th order stream, but increase drastically to the 5 th order stream. $\mathrm{R}_{\mathrm{c}}$ however slightly diminishes and increases again from the 3 rd to the 5 th order stream. Increasing size of the 5 th order stream possibly has caused increase in planiform parameters.

The planiform parameters of the five stream segments are incorporated in Table 2. All the five stream segments are sinuous and the Arubot Segment is the most sinuous one among them. Both meander wavelength and belt width increase with increasing stream order. But the fifth segment shows the diminishing trend probably due to anthropogenic alteration of the river. However, there is a good and high degree of positive correlation between dimensionless ratios (Fig. 5), i.e., meander length ratio (MLR) and meander belt width ratio (MWR).

\section{Geology}

The Kodku watershed comprises of metasedimentary rocks of the Phulchoki Group (Stöcklin, 1980), i.e., the Sopyang and the Chandragiri Formations in the southermost portion (Fig. 6).

(1) The Sopyang Formation comprises dark to yellowish brown (when weathered) thinly bedded calcareous slate, argillaceous limestone and grey metasiltstone. It is well exposed at the left bank of the Kodku River near Badikhel, where it is characterized by highly weathered, highly jointed, medium bedded argillaceous limestone and calcareous slate showing attitude: $\mathrm{N} 50^{\circ} \mathrm{W} / 38^{\circ} \mathrm{SW}$. These lithologies are associated (at about 15 upstream) with moderately weathered laminated grey metasiltstone having attitude: N62 ${ }^{\circ} \mathrm{W} / 80^{\circ} \mathrm{SW}$.

(2) The Chandragiri Formation comprises bluish grey to brown, finely crystalline limestone, phyllite and 
metasandstones. The beds extend NW-SE, and dip southwestward in the southern portion and northeastwards in the northern portion, thus forming the portion of the anticline. A ridge forming bedrock of the Chandragiri

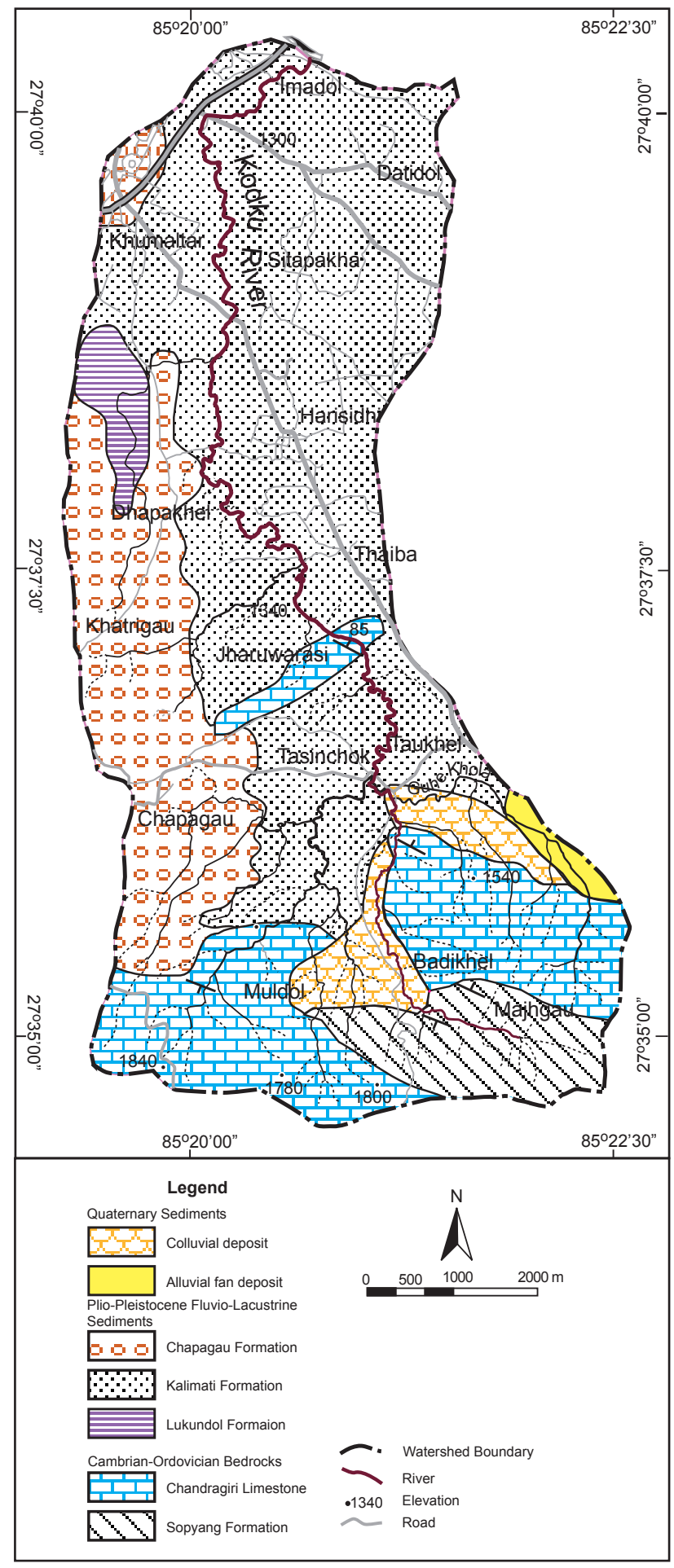

Fig. 6 Geological map of the Kodkhu watershed (after DMG, 1998).
Limestone also exists at Jharuwarasi, where river incises forming a hanging valley towards the south (Fig. 6).

(3) Plio-Pleistocene fluvio-lacustrine sediment: The portion of the western part of the watershed is occupied by the Lukukdol Formation characterized by sandy clayey silt interbedded with gravel, sand, and peat layers. The majority of the northereastern or the eastern half portion of the watershed constitutes the Kalimati Formation. This formation consists of dark silty clay, clayey silt, fine sands and peat layers. The black clay bed of the Kalimati Formation is well exposed on the banks and channel substrate of the third order stream downstream from Badikhel and in the forth and fifth order stream of the Kodku River.

The western half portion of the watershed is occupied by the Chapagaon Formation (DMG, 1998). This formationis equivalent to the earlier classified Pyangaon, Chapagaon and Boregaon Terrace Deposits by Yoshida and Igarashi (1984), and the Itaiti Formation of Sakai (2001). It comprises subrounded to rounded silty sandy gravel occassionally intercalated wtih silty sand, clayey silt, and boulder beds. The Chapagaon Formation is the debris flow deposit which now forms high terraces of the Kodku River.

Adjacent to the bedrocks of the Sopyang and the Chandragiri Formations, colluvial sediments and the alluvial fan deposits form extensive covers. The colluvial sediment contains clay, silt, sand and some gravel, and mainly occurs adjacent to the footslope. The allivial fan deposit of gravel, sandy gravel, sands and silt occurs at extreme east of the southern part of the watershed. Therefore, the Kodku River originates from the bedrocks of the Chandragiri Limestone and the Sopyang Formation, and traverses over the colluvial sediments and basin-fill sediments of the fluvio-lacustrine origin.

\section{Valley types and landforms}

The valley types and related stream types and landforms based on Rosgen (1996). The valley types and related landforms of the Kodku River based on Rosgen (1996) are of the following kinds:

(1) Valley type I: It is a v-shaped alluvial valley, which is structurally confined and controlled by faults. The valley with bedrock is dissected and incised by the stream. It is found in the first and second orders of the Kodku 
main stem portion and at the gorge of the fifth order Kodku River where the river incises the bedrock of limestone. The later is probably uplifted due to associated faulting.

(2) Valley type II: This valley is located in the third order segment of the main stem Kodkhu River. It is characterized by fluvial valley slope with planated terraces and is also dominated by residual, colluvial, and alluvial slopes with few exposures of bedrocks.

(3) Valley type IV: The valley type IV is a classic meandering river valley incised in weathered rock and valley sediments, and is associated with tectonic upliftment of valley. It is distributed in the upstream portion of the fifth order main stem segment of the Kodku River, and is characterized by depositional landforms of alluvial terrace, flood plains and lateral bars.

(4) Valley type VI: This valley is structurally controlled and dominated by colluvial slopes, and is laterally confined. It is found in the upstreammost segment of the third order main stem Kodku River.

(5) Valley type VIII: This valley is a multi river terrace valley, which is a broad valley with gentle down valley elevation relief. It is associated with alluvial terrace, flood plains and lateral bars. This type of valley is observed in the mid to downstream portions of the fifth order main stem Kodku River.

\section{LEVEL I CLASSIFICATION OF RIVER}

Rosgen Level I provides a broad geomorphic characterization to start the classification process. Valley types, landform and fluvial characteristics are described and combined channel relief, shape, and dimension profiles (Rosgen, 1994). Level I analysis requires rigorous map and areal photos to interprete valley features, and stream pattern and profile.

The characteristics in Level I (Table 3) are

(a) Channel pattern relative to single and multiple paths: Plan view morphology mainly the sinuosity of river system.

(b) Channel shape relative to width and depth: Cross section morphology: cross sections differ greatly from deep and narrow to wide and shallow. The cross section morphology also describes the flood plain ranging from well-developed flood plains to virtually no flood plain.

(c) Channel Slope relative to Valley slope: the longitudinal profiles used to represent slope. Slope can be related to bed features and can be described as pools, riffles, rapids, cascades, and steps (Rosgen, 1994).

The Kodku River segments are classified based on the above mentioned criteria (Table 3 ) and are listed in Table 4 and shown in Fig. 7. The river segments are distinguished broadly into three types of rivers, i.e., B, $\mathrm{Aa}+$, and C. All the third order stream segments of the

Table 3: C riteria of Level I classification of stream segments (based on Rosgen (1996))

\begin{tabular}{|c|c|c|c|}
\hline Criteria & & Description & Stream type \\
\hline \multirow[t]{6}{*}{ (1) Pattern } & Relatively straight & Sinuosity, $\mathrm{K}<1.2$ & $\mathrm{~A}, \mathrm{~A}^{\mathrm{a}+}$ \\
\hline & Low sinuosity & Sinuosity, $\mathrm{K}>1.2$ & $\mathrm{~B}, \mathrm{G}$ \\
\hline & Meandering & Sinuosity, $K>1.4$ & $\mathrm{C}, \mathrm{F}$ \\
\hline & Torturously meandering & Sinuosity, $K>1.5$ & E \\
\hline & Complex: braided & Sinuosity, $\mathrm{K}<1.2$ & $\mathrm{D}$ \\
\hline & Complex: anastomosed & Sinuosity, K>1.2 & DA \\
\hline \multirow[t]{5}{*}{ (2) Shape } & Shallow/wide & Highest $\mathrm{W} / \mathrm{D}$ ratio & $\mathrm{D}$ \\
\hline & & Shallow/wide, entrenched meandering channel & $\mathrm{F}$ \\
\hline & & Shallow/wide, low entrenched meandering channe & $\mathrm{C}$ \\
\hline & Deep/narrow & Narrow/deep channel but wider valley & $\mathrm{E}$ \\
\hline & & Low W/D ratio more entrenched than $\mathrm{E}$ & $\mathrm{A}^{\mathrm{a}+}, \mathrm{A}, \mathrm{B}, \mathrm{G}$ \\
\hline \multirow[t]{5}{*}{ (3) Valley slope } & Extremely gentle & $<0.5 \%$ & DA \\
\hline & Gentle & $<2 \%$ & $\mathrm{C}, \mathrm{E}, \mathrm{F}$ \\
\hline & Moderately steep & $<2-4 \%$ & $\mathrm{~B}, \mathrm{G}$ \\
\hline & Steep & $4-10 \%$ & A \\
\hline & Very steep & $>10 \%$ & $\mathrm{~A}^{\mathrm{a}+}$ \\
\hline
\end{tabular}


main stem river are classified as " $\mathrm{B}$ ' type river. The fourth and fifth order stream segments are clasified as ' $\mathrm{C}$ ' type rivers. The fifth order segment at the gorge is classified as ' $\mathrm{A}$ ' type river.

\section{'B' Type Streams}

The ' $\mathrm{B}$ ' type streams are of two types having different valley types, i.e., one of the categories is with VI valley type having bedforms of riffle and rapids, and the another

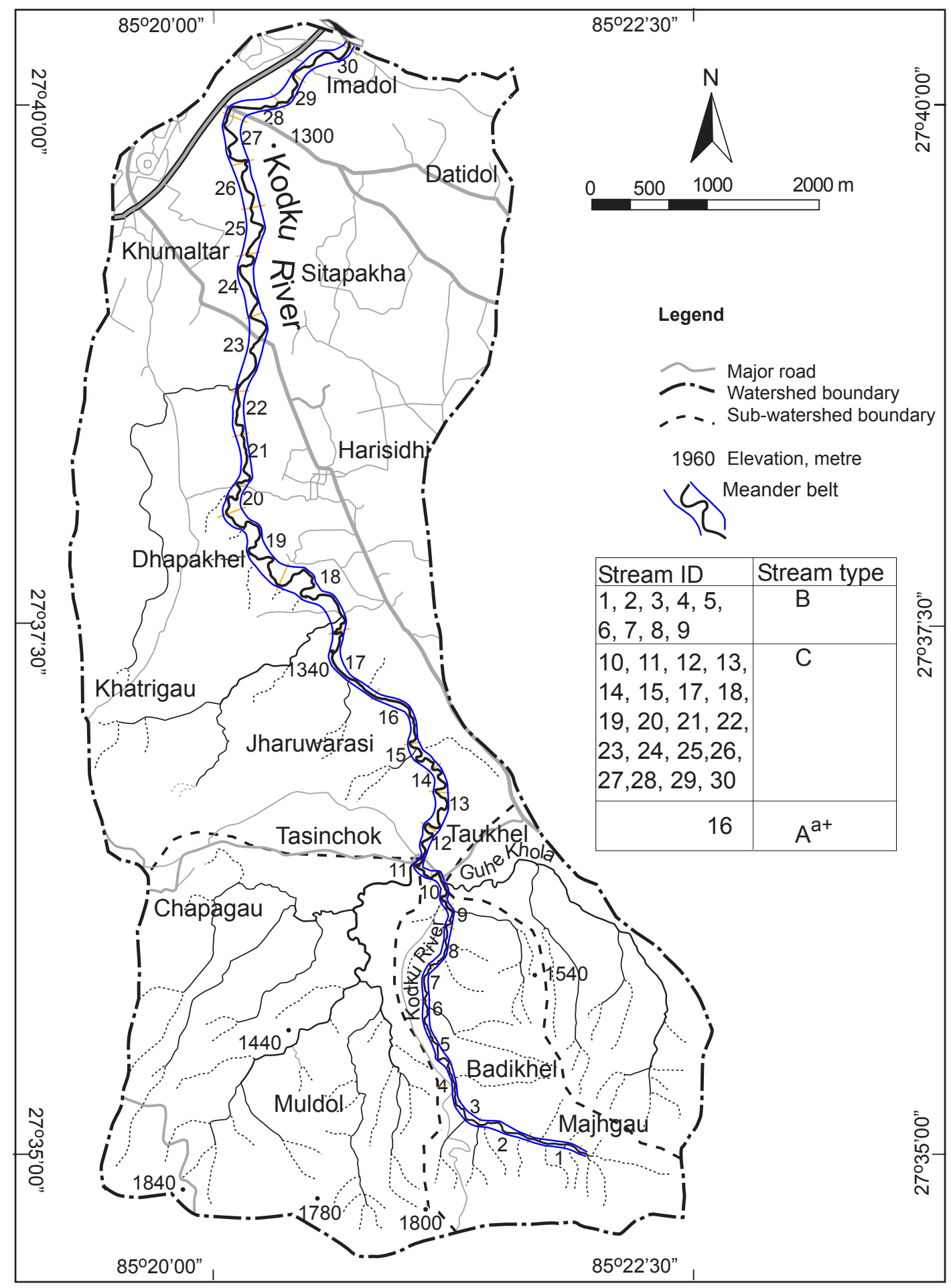

Fig. 7 A map of the Kodku watershed showing stream segment ID and stream type based on Level I classification. 
Table 4: Level I classification of stream segments of the Kodku River

\begin{tabular}{|c|c|c|c|c|c|c|c|c|c|}
\hline Stre & eam & $\begin{array}{l}\text { *Valley } \\
\text { type }\end{array}$ & & & Pattern & Shape & $\begin{array}{l}\text { Channel } \\
\text { slope }\end{array}$ & Bed features & $\begin{array}{c}\text { Stream } \\
\text { Type }\end{array}$ \\
\hline ID & Order & & & & Sinuosity & & & & \\
\hline 1 & 3 & VI & & 1.03 & Relatively straight & Narrow/deep & $2-4 \%$ & Riffles, rapids & is B \\
\hline 2 & 3 & VI & Structural valley & 1.09 & Relatively straight & Narrow/deep & $2-4 \%$ & Riffles, rapids & ls B \\
\hline 3 & 3 & VI & & 1.08 & Relatively straight & Narrow/deep & $2-4 \%$ & Riffles, rapids & ls B \\
\hline 4 & 3 & II & & 1.01 & Relatively straight & Narrow/deep & $2-4 \%$ & Riffles, pools & S B \\
\hline 5 & 3 & II & Fluvial valley slope & 1.26 & Low sinuosity & Narrow/deep & $2-4 \%$ & Riffles, pools & S B \\
\hline 6 & 3 & II & dominated by colluvial, & 1.04 & Relatively straight & Narrow/deep & $2-4 \%$ & Riffles, pools & S B \\
\hline 7 & 3 & II & alluvial and residual soil & 1.10 & Relatively straight & Narrow/deep & $2-4 \%$ & Riffles, pools & S B \\
\hline 8 & 3 & II & slopes & 1.09 & Relatively straight & Narrow/deep & $2-4 \%$ & Riffles, pools & $\mathrm{S} B$ \\
\hline 9 & 3 & II & & 1.20 & Low sinuosity & Narrow/deep & $2-4 \%$ & Riffles, pools & $\mathrm{s} B$ \\
\hline 10 & 4 & IV & Classic meandering river & 1.32 & Low sinuosity & Wide/shallow & $<2 \%$ & Riffles, pools & $\mathrm{S} \mathrm{C}$ \\
\hline 11 & 4 & IV & valley, structurally & 1.24 & Low sinuosity & Wide/shallow & $<2 \%$ & Riffles, pools & $\mathrm{s} C$ \\
\hline 12 & 5 & IV & controlled and incised in & 1.40 & Meandering & Wide/shallow & $<2 \%$ & Riffles, pools & $\mathrm{S} C$ \\
\hline 13 & 5 & IV & $\begin{array}{l}\text { weathered rocks, and or } \\
\text { associated with }\end{array}$ & 1.68 & Tortuously meandering & Wide/shallow & $<2 \%$ & Riffles, pools & $\mathrm{S} C$ \\
\hline 14 & 5 & IV & $\begin{array}{l}\text { associated with } \\
\text { tectonically uplifted }\end{array}$ & 1.65 & Tortuously meandering & Wide/shallow & $<2 \%$ & Riffles, pools & $\mathrm{S} \mathrm{C}$ \\
\hline 15 & 5 & IV & valley & 1.63 & Tortuously meandering & Wide/shallow & $<2 \%$ & Riffles, pools & $\mathrm{S} \mathrm{C}$ \\
\hline 16 & 5 & I & Structurally controlled & 1.09 & Relatively straight & Narrow/deep & $>10 \%$ & Vertical drop & $\mathrm{A}^{\mathrm{a}+}$ \\
\hline 17 & 5 & VIII & & 1.14 & Relatively straight & Wide/shallow & $<2 \%$ & Riffles, pools & $\mathrm{s} \mathrm{C}$ \\
\hline 18 & 5 & VIII & & 1.49 & Meandering & Wide/shallow & $<2 \%$ & Riffles, pools & $\mathrm{S} C$ \\
\hline 19 & 5 & VIII & & 1.61 & Tortuously meandering & Wide/shallow & $<2 \%$ & Riffles, pools & $\mathrm{S} \mathrm{C}$ \\
\hline 20 & 5 & VIII & & 1.37 & Low Sinuosity & Wide/shallow & $<2 \%$ & Riffles, pools & $\mathrm{S} \mathrm{C}$ \\
\hline 21 & 5 & VIII & & 1.22 & Low Sinuosity & Wide/shallow & $<2 \%$ & Riffles, pools & $\mathrm{S} \mathrm{C}$ \\
\hline 22 & 5 & VIII & Multi river terraces & 1.10 & Relatively straight & Wide/shallow & $<2 \%$ & Riffles, pools & $\mathrm{S} \mathrm{C}$ \\
\hline 23 & 5 & VIII & positioned laterally along & 1.25 & Low Sinuosity & Wide/shallow & $<2 \%$ & Riffles, pools & $\mathrm{S} \mathrm{C}$ \\
\hline 24 & 5 & VII & downvalley elevation & 1.37 & Low sinuosity & Wide/shallow & $<2 \%$ & Riffles, pools & $\mathrm{S} C$ \\
\hline 25 & 5 & VIII & relief & 1.31 & Low sinuosity & Wide/shallow & $<2 \%$ & Riffles, pools & $\mathrm{S} C$ \\
\hline 26 & 5 & VII & & 1.19 & Relatively straight & Wide/shallow & $<2 \%$ & Riffles, pools & $\mathrm{S} C$ \\
\hline 27 & 5 & VIII & & 1.47 & Meandering & Wide/shallow & $<2 \%$ & Riffles, pools & $\mathrm{S} C$ \\
\hline 28 & 5 & VIII & & 1.25 & Low Sinuosity & Wide/shallow & $<2 \%$ & Riffles, pools & $\mathrm{S} C$ \\
\hline 29 & 5 & VIII & & 1.23 & Low Sinuosity & Wide/shallow & $<2 \%$ & Riffles, pools & $\mathrm{S} C$ \\
\hline 30 & 5 & VIII & & 1.19 & Relatively straight & Wide/shallow & $<2 \%$ & Riffles, pools & $\mathrm{S} \mathrm{C}$ \\
\hline
\end{tabular}

*Valley type: $\mathrm{I}=$ Alluvial valley confined and is structurally controlled, II = Fluvial valley slope dominated by colluvial, alluvial and residual soil slopes, IV = Classic meandering river, structurally controlled and incised in weathered rocks, and or associated with tectonically uplifted valley, VI = Structurally controlled valley with dominated colluvial slopes, pattern controlled by confined laterally controlled valley, $\mathrm{VIII}=$ Multi river terraces positioned laterally along broad vallyes with gentle downvalley elevation relief.

\section{'C' Type Stream}

with II valley type having bedforms of riffles and pools. However, both are characterized low sinuosity and narrow/deep stream segments. They have moderately steep slopes (ranging from 2 to $4 \%$ ). The 'B' stream types with VI valley type are located in the upstream portion of the third order main stem Kodku River, wehreas the 'B' type streams with II valley type are locate in the down stream portion of the third order mainstem.
The ' $C$ ' type streams commence with the initiation of the fourth order main stem Kodku River. The ' $\mathrm{C}$ ' type streams have IV type valleys, which are classic meandering river valleys that are structurally controlled and incised and associated with tectonically uplifted valleys. These also have variable degrees of sinuosity ranging from tortuously meandering to relatively straight segments, and shallow and wide channels with well develop riffles and pool bedforms. The channel slope in these streams is less than $2 \%$. 


\section{'Aa+' Type Stream}

The 'Aa+' type stream is located at Jharuwarasi (Fig. 7), where the fifth order main stem Kodku River incises a bedrock forming the hanging valley upstream of this location. The stream is more or less straight with narrow/deep channel and very high channel slope $(>10 \%)$. The incision is marked by presence of fall or a vertical drop of river, and presence of a gorge.

\section{RESULTS OF LEVEL II INVENTORY OF STREAM STABILITY ASSESSMENT}

\section{Hydrologic Parameters}

Table 5 lists the hydrologic parameters of the Kodku River. The width $\left(\mathrm{W}_{\mathrm{bkf}}\right)$ is the highest in the Harisidhi Segment $(15.6 \mathrm{~m})$, and is the lowest $(5.8 \mathrm{~m})$ in the Taukhel Segment (Table 5). Maximum depth at bankfull $\left(D_{\max }\right)$ is the highest in the Badikhel Segment $(1.5 \mathrm{~m})$, while it is the least in the Arubot and the Thaiba Segments $(0.8 \mathrm{~m})$. The mean depth at bankfull $\left(\mathrm{D}_{\text {bkf }}\right)$ varies between 0.5 and $0.8 \mathrm{~m}$ and is almost ranging narrowly. Hydraulic radius varies between 0.5 and $0.6 \mathrm{~m}$. The cross-sectional area is relatively large in the Harisidhi Segment (10 sq. m) and the Badikhel Segment (6.2 sq. m), whereas it is almost similar in the other segments (3.3 to $4.2 \mathrm{sq} . \mathrm{m}$ ).

Width/Depth ratio of the Badikhel and the Taukhel Segments is similar (10.5). It is 1.5 times larger in the Arubot and the Thaiba Segments, while it is nearly three times larger in the Harisidhi Segments. The cross-sectional area is relatively large in the Harisidhi and the Badikhel Segments, whereas it is almost similar in the other segments.

The bank height ratio (BHR) increases from the Badikhel (1.6) to the Taukhel (2.2) and then diminishes to the Arubot Segment (1.8). BHR then gradually increases towards the Harisidhi Segments. Since BHR varies between 1.6 to 2.4 the banks are prone to flooding.

Entrenchment ratio (ER), which is a parameter to determine if the stream has incised to the extent beyond the abandonment of its flood plain, ranges from 1.7 to 7.1, and the Badikhel Segment is relatively more entrenched (1.7) compared to the other segments while the Taukhel Segment is the least entrenched (7.1) among them. Since ER is more than 1.6, the stream segments of the Kodku River are considered moderate to low entrenched.

Table 5: Hydrologic parameters of the Kodku River

\begin{tabular}{|c|c|c|c|c|c|}
\hline & $\begin{array}{l}\text { Badikhel } \\
\text { Segment }\end{array}$ & $\begin{array}{l}\text { Taukhel } \\
\text { Segment }\end{array}$ & $\begin{array}{l}\text { Arubot } \\
\text { Segment }\end{array}$ & $\begin{array}{l}\text { Thaiba } \\
\text { Segment }\end{array}$ & $\begin{array}{l}\text { Harisidhi } \\
\text { Segment }\end{array}$ \\
\hline \multicolumn{6}{|l|}{ Riffle cross-section } \\
\hline Width at bankfull, $\mathrm{W}_{\mathrm{bkf}}(\mathrm{m})$ & 10.3 & 5.8 & 8.1 & 8.0 & 15.2 \\
\hline Max. depth at bankfull, $\mathrm{D}_{\max }(\mathrm{m})$ & 1.5 & 1.0 & 0.8 & 0.8 & 1.0 \\
\hline Width of flood prone area, $\mathrm{W}_{\mathrm{fpa}}(\mathrm{m})$ & 16.8 & 40.7 & 50 & 42 & 53.2 \\
\hline Max. depth at top of low bank, $\mathrm{D}_{\text {tob }}(\mathrm{m})$ & 2.4 & 2.2 & 1.5 & 1.7 & 2.3 \\
\hline Mean depth at bankfull, $\mathrm{D}_{\mathrm{bkf}}=\mathrm{A}_{\mathrm{bkf}} / \mathrm{W}_{\mathrm{bkf}}(\mathrm{m})$ & 0.8 & 0.6 & 0.5 & 0.5 & 0.7 \\
\hline Entrenchment ratio, $\mathrm{ER}=\mathrm{W}_{\mathrm{bkf}} / \mathrm{D}_{\mathrm{bkf}}$ & 1.7 & 7.1 & 6.3 & 5.4 & 3.7 \\
\hline Hydraulic radius, $\mathrm{R}=\mathrm{A}_{\mathrm{bkf}} \mathrm{f}\left(2 \mathrm{D}_{\mathrm{bkf}}+\mathrm{W}_{\mathrm{bkf}}\right)(\mathrm{m})$ & 0.6 & 0.5 & 0.5 & 0.5 & 0.6 \\
\hline Width/depth ratio, W/D ratio & 14.3 & 10.5 & 15.2 & 15.3 & 29.5 \\
\hline Bank height ratio, $\mathrm{BHR}=\mathrm{D}_{\mathrm{tob}} / \mathrm{D}_{\max }$ & 1.6 & 2.2 & 1.8 & 2.0 & 2.4 \\
\hline Max depth ratio, $\mathrm{D}_{\max } / \mathrm{D}_{\mathrm{bkf}}$ & 1.9 & 1.8 & 1.6 & 1.6 & 1.6 \\
\hline Bankfull cross-sectional area, $\mathrm{A}_{\mathrm{bkf}}\left(\mathrm{m}^{2}\right)$ & 6.2 & 3.3 & 4.4 & 4.2 & 10 \\
\hline \multicolumn{6}{|l|}{ Pool cross-section } \\
\hline Pool width, $\mathrm{W}_{\text {pool }}(\mathrm{m})$ & 9.7 & 6.1 & 7.4 & 7.7 & 13.9 \\
\hline Pool area, $\mathrm{A}_{\text {pool }}\left(\mathrm{m}^{2}\right)$ & 7.0 & 4.1 & 5.4 & 3.7 & 7.1 \\
\hline Pool max depth, $\mathrm{D}_{\text {pool }}(\mathrm{m})$ & 1.4 & 1.2 & 1.2 & 0.9 & 1.0 \\
\hline Slope of channel, $\mathrm{S}_{\text {average }}=\Delta \mathrm{Elv} / \Delta \mathrm{L}_{\mathrm{tw}}(\mathrm{m} / \mathrm{m})$ & 0.0055 & 0.0023 & 0.0007 & 0.0009 & 0.0002 \\
\hline Bed material, $\mathrm{D}_{50}(\mathrm{~m})$ & 0.02 & 0.00003 & 0.001 & 0.002 & 0.003 \\
\hline
\end{tabular}




\section{Longitudinal Profile}

The longitudinal profile of the Kodku River reflects its gradient throughout its length (Fig. 8). The average slopes of the 5th, 4th and 3rd order stretches are 0.83 $\mathrm{m} / \mathrm{m}, 1.59 \mathrm{~m} / \mathrm{m}$ and $5.86 \mathrm{~m} / \mathrm{m}$, respectively. The average slope of the Kodku River is $3.42 \mathrm{~m} / \mathrm{m}$. Two distinct knick points, one close to the emergence of the 3 rd order and another close to the emergence of the 4 th order streams, are present. The 3rd and 4th order main stem Kodku River stretches have tendency to erode their channel. Similarly, there is a knick point at about $1.6 \mathrm{~km}$ from the emergence of the 5 th order stream, forming a water fall. Bedrock of limestone is situated therein, hence forming a hanging valley upstream of the water fall. There remains tendency of headward erosion at this location.

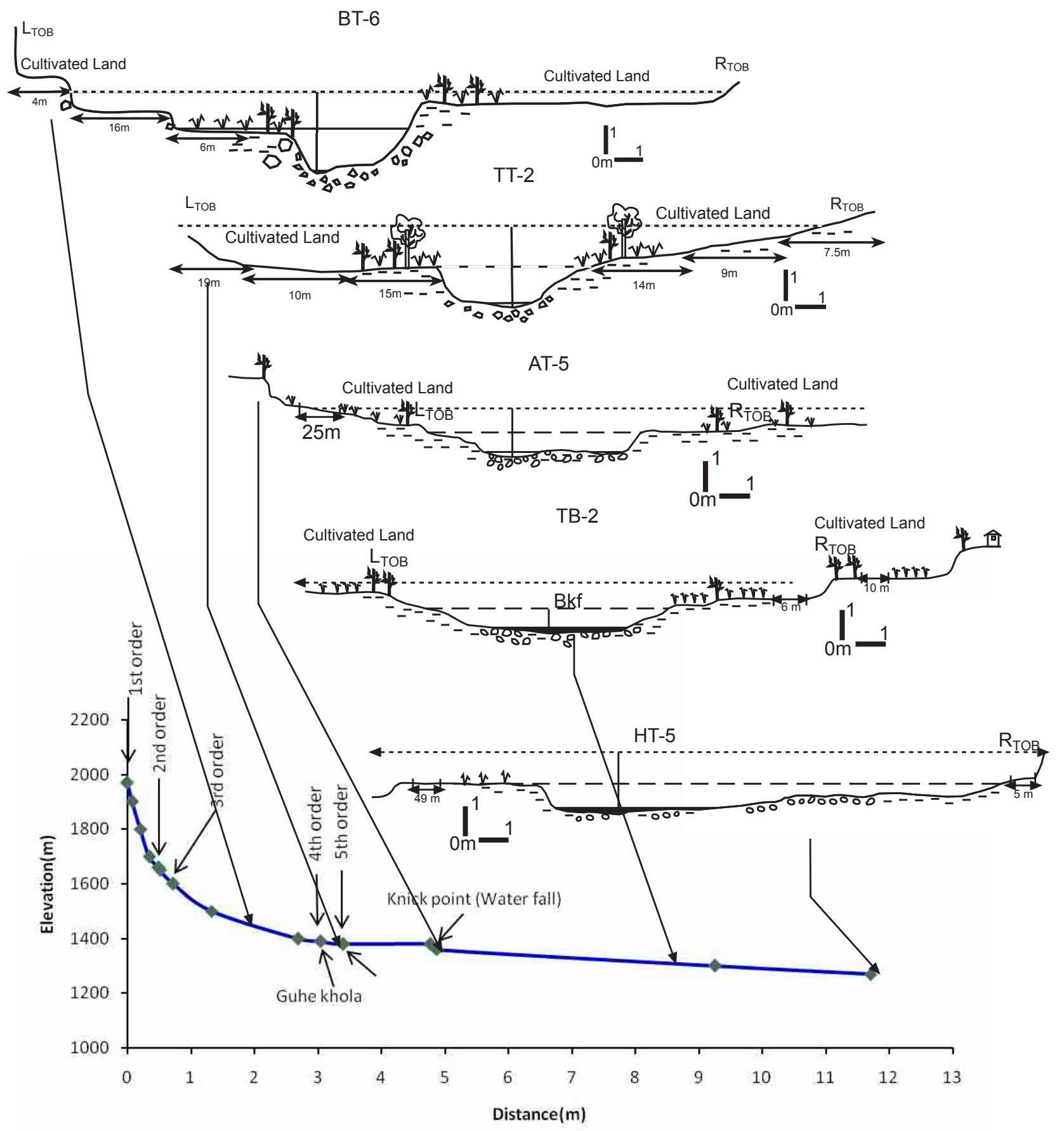

Fig. 8 A Longitudinal profile of the Kodku River. 
Table 7: Results of Wolman pebble count on segments of the Kodku River

\begin{tabular}{|c|c|c|c|c|c|c|c|c|c|c|c|c|c|c|c|c|c|}
\hline \multirow{3}{*}{ Particle } & \multirow{3}{*}{ Description } & \multirow{3}{*}{$\begin{array}{c}\text { Size } \\
\text { Category } \\
(\mathrm{mm})\end{array}$} & \multicolumn{3}{|c|}{$\begin{array}{c}\text { Badhikhel } \\
\text { Segment }\end{array}$} & \multicolumn{3}{|c|}{$\begin{array}{l}\text { Taukhel } \\
\text { Segment }\end{array}$} & \multicolumn{3}{|c|}{$\begin{array}{c}\text { Arubot } \\
\text { Segment }\end{array}$} & \multicolumn{3}{|c|}{$\begin{array}{l}\text { Thaiba } \\
\text { Segment }\end{array}$} & \multicolumn{3}{|c|}{$\begin{array}{l}\text { Harisidhi } \\
\text { Segment }\end{array}$} \\
\hline & & & & & $\overline{\%}$ & & & & & & $\overline{\%}$ & & & $\overline{\%}$ & & & $\overline{\%}$ \\
\hline & & & $* \mathrm{TF}$ & $\% \mathrm{~F}$ & $\mathrm{CF}$ & $\mathrm{TF}$ & $\% \mathrm{~F}$ & $\% \mathrm{CF}$ & $\mathrm{TF}$ & $\% \mathrm{~F}$ & $\mathrm{CF}$ & $\mathrm{TF}$ & $\% \mathrm{~F}$ & $\mathrm{CF}$ & $\mathrm{TF}$ & $\% \mathrm{~F}$ & $\mathrm{CF}$ \\
\hline \multirow{5}{*}{$\begin{array}{l}\text { Bedrock } \\
\text { Boulder }\end{array}$} & & 4096 & & & & & & & & & & & & & & & \\
\hline & Very Large & $2048-4096$ & & & & & & & & & & & & & & & \\
\hline & Large & $1024-2048$ & 1 & 0.5 & 0.5 & & & & & & & & & & & & \\
\hline & Medium & $512-1024$ & 4 & 2 & 2.5 & & & & & & & & & & & & \\
\hline & Small & $256-512$ & 7 & 3.5 & 6 & 1 & 0.5 & 0.5 & & & & & & & & & \\
\hline \multirow[t]{2}{*}{ Cobble } & Large & $128-256$ & 11 & 5.5 & 11.5 & 2 & 1 & 1.5 & & & & & & & & & \\
\hline & Small & $64-128$ & 29 & 15 & 26 & 4 & 2 & 3.5 & & & & & & & & & \\
\hline \multirow[t]{5}{*}{ Pebble } & Very coarse & $32-64$ & 28 & 14 & 40 & 22 & 11 & 14.5 & & & & & & & & & \\
\hline & Coarse & $16-32$ & 30 & 15 & 55 & 28 & 14 & 28.5 & & & & & & & & & \\
\hline & Medium & $8.0-16$ & 11 & 5.5 & 60.5 & 18 & 9 & 37.5 & 6 & 3 & 3 & 20 & 10 & 10 & 17 & 8.5 & 8.5 \\
\hline & Fine & $4.0-8$ & 3 & 1.5 & 62 & 1 & 0.5 & 38 & 34 & 17 & 20 & 43 & 21.5 & 32 & 64 & 32 & 41 \\
\hline & Very fine & $2.0-4.0$ & 0 & 0 & 62 & 0 & 0 & 38 & 37 & 18.5 & 39 & 32 & 16 & 48 & 51 & 25.5 & 66 \\
\hline \multirow[t]{5}{*}{ Sand } & Very coarse & $1.0-2.0$ & 0 & 0 & 62 & 1 & 0.5 & 38.5 & 25 & 12.5 & 51 & 15 & 7.5 & 55 & 11 & 5.5 & 72 \\
\hline & Coarse & $0.5-1.0$ & 0 & 0 & 62 & 0 & 0 & 38.5 & 6 & 3 & 54 & 2 & 1 & 56 & 0 & 0 & 72 \\
\hline & Medium & $0.250-0.500$ & 0 & 0 & 62 & 0 & 0 & 38.5 & 0 & 0 & 54 & 0 & 0 & 56 & 1 & 0 & 72 \\
\hline & Fine & $0.125-0.250$ & 0 & 0 & 62 & 0 & 0 & 38.5 & 0 & 0 & 54 & 0 & 0 & 56 & 0 & 0 & 72 \\
\hline & Very fine & $0.063-0.125$ & 0 & 0 & 62 & 0 & 0 & 38.5 & 1 & 0.5 & 55 & 1 & 0.5 & 57 & 0 & 0 & 72 \\
\hline \multirow[t]{2}{*}{ Silt/Clay } & & $<0.063$ & 76 & 38 & 100 & 123 & 61.5 & 100 & 91 & 45.5 & 100 & 87 & 43.5 & 100 & 56 & 28 & 100 \\
\hline & & & 200 & 100 & & 200 & 100 & & 200 & 100 & & 200 & 100 & & 200 & 99.5 & \\
\hline
\end{tabular}

*TF=Total frequency, $\mathrm{CF}=$ Cumulative frequency, $\mathrm{F}=$ Frequency

\section{RIVERBED MATERIAL SIZE DISTRIBUTION}

Wolman's (1954) pebble count was adopted to characterize riverbed material of individual segments. Eight transects in each segment were traversed for twentyfive counts. Fig. 9 shows plots from the cumulative frequency percent of clasts (Table 7). Based on median size, the sediments of the Badikhel Segment are coarse pebble, whereas those for Taukhel Segment are silt/clay mixture. The median sizes of the Arubot Segment and the Thaiba Segment both belong to very coarse sand. The Harisidhi Segment possesses very fine pebbles as substrate material. In the Badikhel and the Taukhel Segments, the size distribution of 0.1 to $4 \mathrm{~mm}$ range is almost absent while 0,1 to $1 \mathrm{~mm}$ size grades are actually missing in the rest of the segments showing gap graded distribution of the riverbed material and there are dominance of either gravel or silt/clay sediments.

\section{STREAM CLASSIFICATION}

Morphological characteristics (Rosgen, 1994) viz ER, W/D ratio, K, slope and bed material were adopted for the classification of the stream. The Kodku River segments from the south to the north are classified as C4c, C6c-, C5c-, C5c- and C4c-streams, respectively (Table 8).

\section{Badikhel Segment (B4c-type Stream)}

The Badikhel Segment is slightly entrenched $(>2.2)$ with moderate W/D ratio $(\sim 12)$ and low sinuosity $(K=$ $1.2)$ with bed material of gravel and silt/clay mixture. The slope is very low $(0.006 \mathrm{~m} / \mathrm{m})$. Therefore, this segment is classified as C4c-type stream. Small point bars, point bars and side bars characterize the deposition pattern of this stream (based on Rosgen's (1994) scheme). Pools and riffles are present along with the presence of step pools. Riparian vegetation along the river corridor is poor, and constitutes mainly shrub and grass, and minorly few trees and bamboos (Fig. 10) forming a discontinuous and linear distribution. Most of the reaches of the corridor are accompanied by cultivated and few houses. The river segment has been affected by clearing of the riparian vegetation, bank encroachment, and solid waste disposed from settlement areas. 

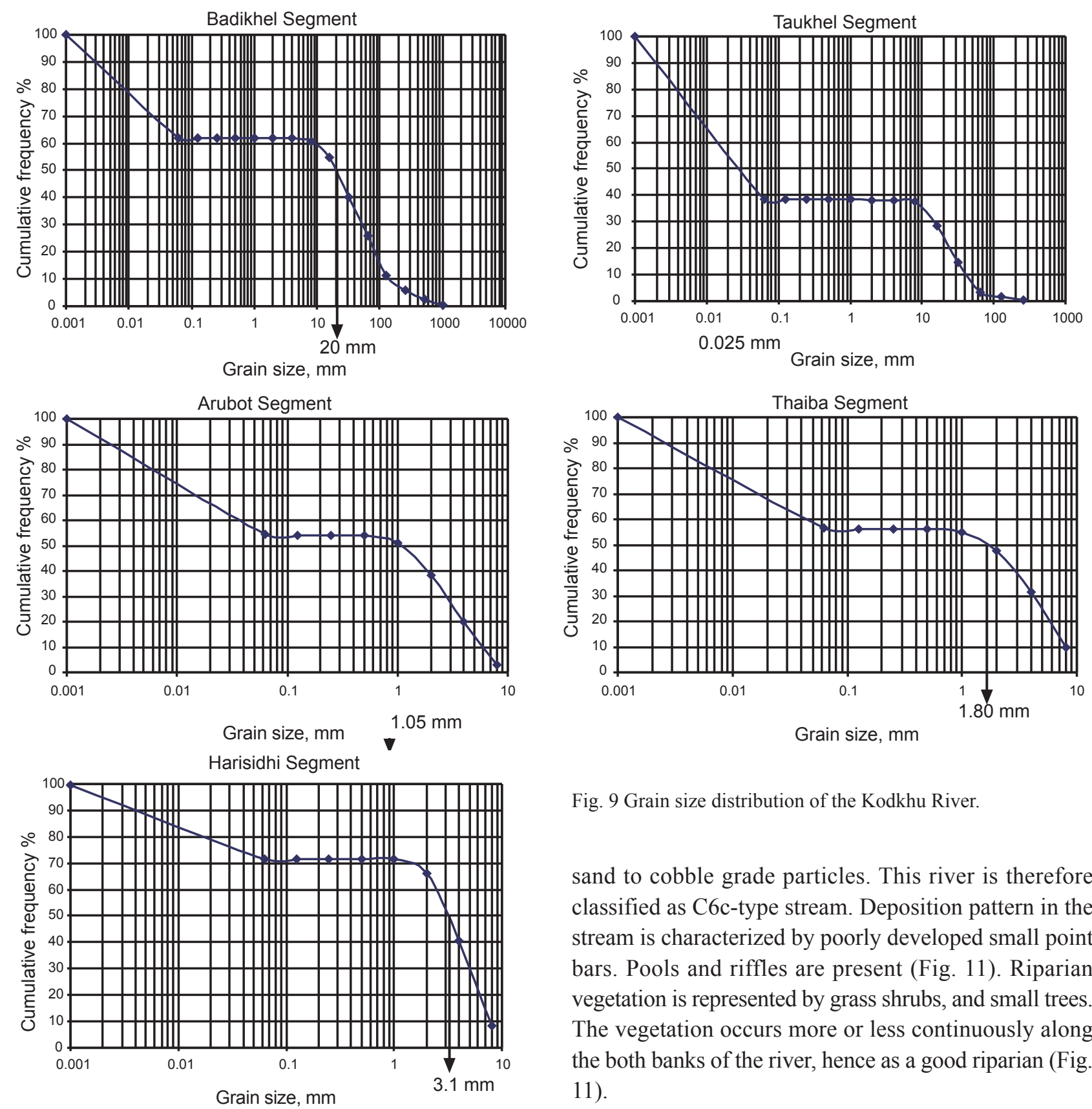

Fig. 9 Grain size distribution of the Kodkhu River.

sand to cobble grade particles. This river is therefore classified as C6c-type stream. Deposition pattern in the stream is characterized by poorly developed small point bars. Pools and riffles are present (Fig. 11). Riparian vegetation is represented by grass shrubs, and small trees. The vegetation occurs more or less continuously along the both banks of the river, hence as a good riparian (Fig. $11)$.

\section{Taukhel Segment (C6c-type Stream)}

The Taukhel Segment, which lies in the fourth order main stem, has a broad valley with terraces associated with well defined flood plains. This segment is slightly entrenched $(E R=7.10)$ with well defined meandering channel $(\mathrm{K}=1.3)$, moderate $\mathrm{W} / \mathrm{D}$ ratio $(10.5)$, and very low gradient $(0.002 \mathrm{~m} / \mathrm{m})$. The bed material comprises dominantly the silt/clay material and subordinately coarse

\section{Arubot Segment (C4c-type Stream)}

The Taukhel Segment, that lies in the fifth order main stem, possesses a broad valley with terraces and is associated with well defined flood plains. It is slightly entrenched $(E R=6.30)$ with very well defined highly sinuous meandering channel $(\mathrm{K}=1.7)$, moderate to high W/D ratio (15.2), and very low gradient $(0.0007 \mathrm{~m} / \mathrm{m})$. The bed material comprises dominantly the pebbles to 
N. K. Tamrakar et al./ Bulletin of the Department of Geology, Vol. 16, 2013, pp. 1-20

Table 8: Summary of classification of the Kodkhu River

\begin{tabular}{|c|c|c|c|c|c|c|c|c|c|c|}
\hline \multirow{3}{*}{$\begin{array}{r}\text { Attributes } \\
\text { Entrenchment ratio, ER }\end{array}$} & \multicolumn{10}{|c|}{ Segments } \\
\hline & \multicolumn{2}{|c|}{ Badikhel } & \multicolumn{2}{|c|}{ Taukhel } & \multicolumn{2}{|c|}{ Arubot } & \multicolumn{2}{|c|}{ Thaiba } & \multicolumn{2}{|c|}{ Harisiddhi } \\
\hline & 1.69 & B & 7.10 & $\mathrm{E}, \mathrm{C}$ & 6.30 & $\mathrm{E}, \mathrm{C}$ & 5.40 & E, C & 3.70 & $\mathrm{E}, \mathrm{C}$ \\
\hline Width/depth ratio, $\mathrm{W} / \mathrm{D}=\mathrm{W}_{\mathrm{bkf}} / \mathrm{D}_{\mathrm{bkf}}$ & 14.28 & B & 10.50 & $\mathrm{E}, \mathrm{C}$ & 15.20 & $\mathrm{C}$ & 15.30 & $\mathrm{C}$ & 29.50 & $\mathrm{C}$ \\
\hline Sinuosity, $\mathrm{K}=\mathrm{L}_{\text {thalweg }} / \mathrm{L}_{\text {valley }}(\mathrm{m} / \mathrm{m})$ & 1.20 & $\mathrm{~B}$ & 1.30 & $\mathrm{C}$ & 1.70 & $\mathrm{C}$ & 1.20 & $\mathrm{C}$ & 1.20 & $\mathrm{C}$ \\
\hline Slope of channel, $S_{\text {average }}=\Delta \mathrm{Elv} / \Delta \mathrm{L}_{\text {thalweg }}(\mathrm{m} / \mathrm{m})$ & 0.006 & $\mathrm{Bc}$ & 0.002 & $\mathrm{Cc}$ & 0.0007 & $\mathrm{C}$ & 0.0009 & $\mathrm{Cc}$ & 0.0002 & $\mathrm{Cc}$ \\
\hline Channel material, $\mathrm{D}_{50}(\mathrm{~m})$ & 0.020 & $\mathrm{~B} 4 \mathrm{c}$ & 0.00003 & $\mathrm{C} 6 \mathrm{c}$ & 0.001 & $\mathrm{C} 5 \mathrm{c}$ & 0.002 & $\mathrm{C} 5 \mathrm{c}$ & 0.003 & $\mathrm{C} 4 \mathrm{c}$ \\
\hline Dominant channel material & $\begin{array}{l}\text { Coarse } \\
\text { pebble }\end{array}$ & & Silt/Clay & & $\begin{array}{l}\text { Pebble } \\
\text { to very } \\
\text { coarse } \\
\text { sand }\end{array}$ & & $\begin{array}{l}\text { Pebble } \\
\text { to very } \\
\text { coarse } \\
\text { sand }\end{array}$ & & $\begin{array}{l}\text { Very } \\
\text { fine } \\
\text { pebble }\end{array}$ & \\
\hline Rosgen Stream Type & & $\mathrm{B} 4 \mathrm{c}$ & & C6c & & $\mathrm{C} 4 \mathrm{c}$ & & $\mathrm{C} 4 \mathrm{c}$ & & $\mathrm{C} 4 \mathrm{c}$ \\
\hline
\end{tabular}
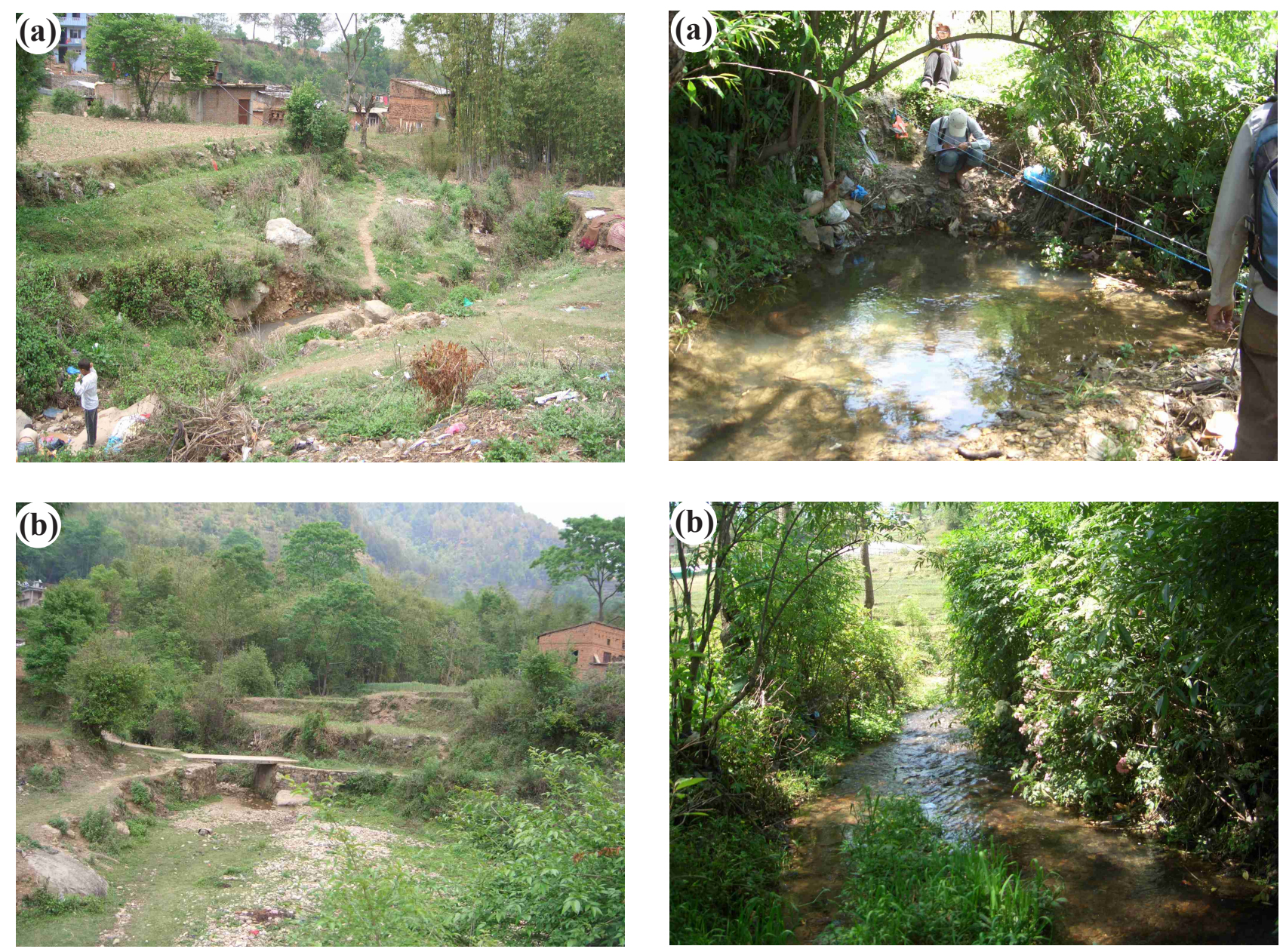

Fig. 10 (a) Downstream view from the transect BT-1 in the Badikhel Segment, and (b) Upstream view from the transect BT3 in the Badikhel Segment.

Fig. 11 (a) Transects in the Taukhel Segment, and (b) Upstream view from the transect BT-3 in the Taukhel Segment. 

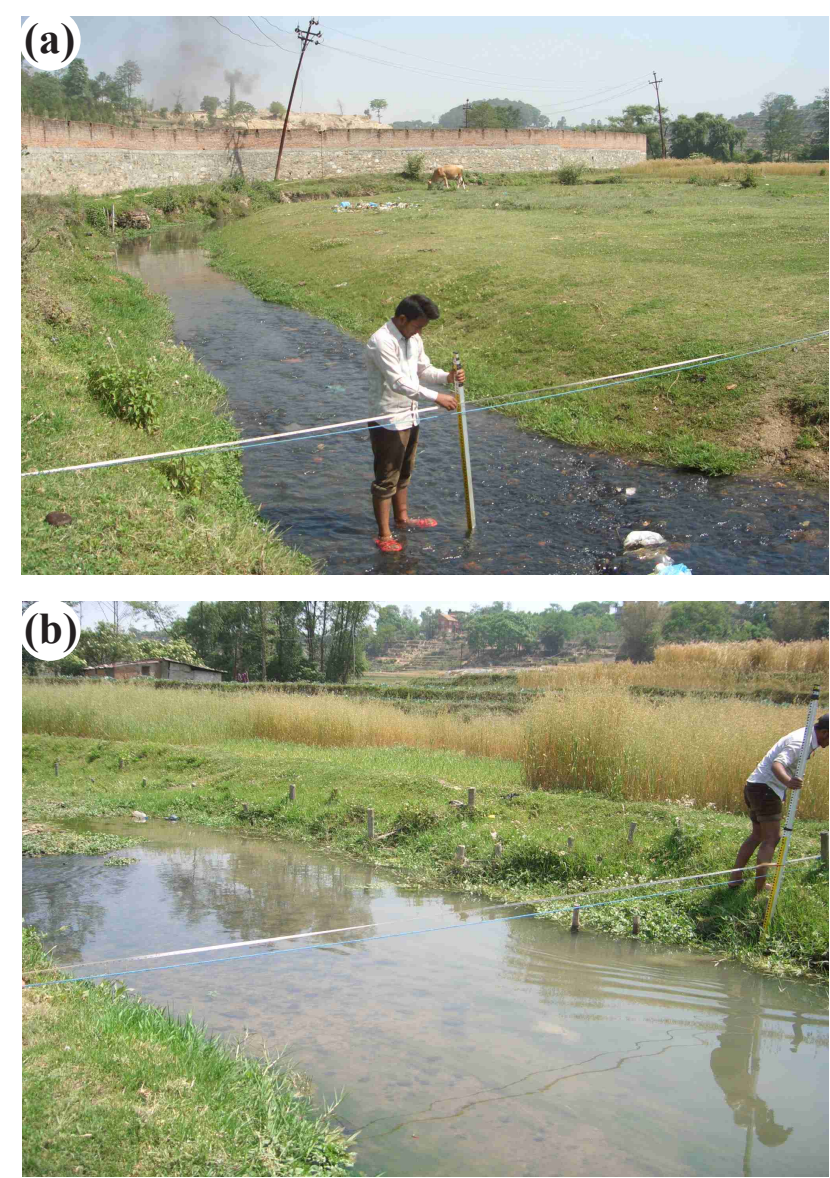

Fig. 5.12 (a) Transects in the Arubot Segment, and (b) Upstream view from the transect BT-3 in the Arubot Segment.

coarse sand and subordinately clay/silt. The river is classified as C4c-type stream. There are well developed point bars of muddy pebbly sediment (Fig. 12). Pools and riffles are also present. Riparian vegetation is patchy and mostly poor consisting of only shrubs and herbs.

\section{Thaiba Segment (C4c-type Stream)}

The Thaiba Segment, that lies in the fifth order main stem, possesses a broad valley with terraces and is associated with well defined flood plains . It is slightly entrenched $(E R=5.40)$ (Fig. 5.13) with well defined sinuous channel $(\mathrm{K}=1.2)$, moderate to high $\mathrm{W} / \mathrm{D}$ ratio (15.3), and very low gradient $(0.0009 \mathrm{~m} / \mathrm{m})$. The bed material comprises dominantly the pebbles to coarse sand and subordinately clay/silt. Therefore, the segment is classified as C4c-type stream. There are well developed point bars of muddy pebbly sediment (Fig. 13), pools
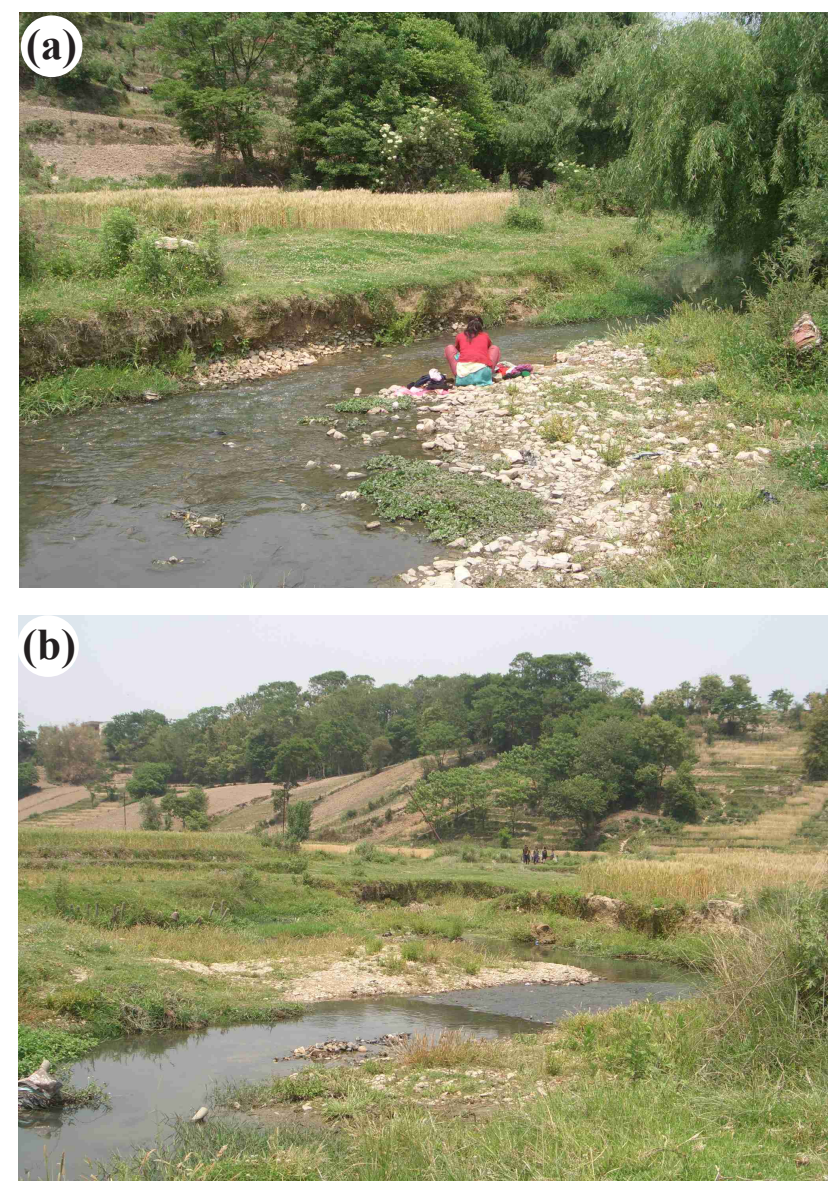

Fig. 5.13 (a) Downstream view of the transect-1 in the Thaiba Segment, and (b) Downstream view of the transect- 4 in the Thaiba Segment.

and riffles. The floodplains and lower terraces are used for cultivation. Raparian vegetation in the segment is poor, and patchy. Mostly it is composed of shrubs and herbs only, but in some instances contain sparse trees.

\section{Harisidhi Segment (C4c-type Stream)}

The Harisidhi Segment, belonging to the fifth order main stem, possesses a very wide valley with terraces and is associated with well defined very wide flood plains. It is slightly entrenched $(E R=3.70)$ with well defined sinuous channel $(\mathrm{K}=1.2)$, high $\mathrm{W} / \mathrm{D}$ ratio (29.5), and very low gradient $(0.0002 \mathrm{~m} / \mathrm{m})$. The bed material comprises dominantly the pebbles to coarse sand and subordinately clay/silt. Therefore, the segment is classified as C4c-type stream. There are well developed point bars of muddy pebbly sediment (Fig. 14), pools and riffles. The floodplains and lower terraces are used for cultivation as in the previous segments, but the floodplains are 

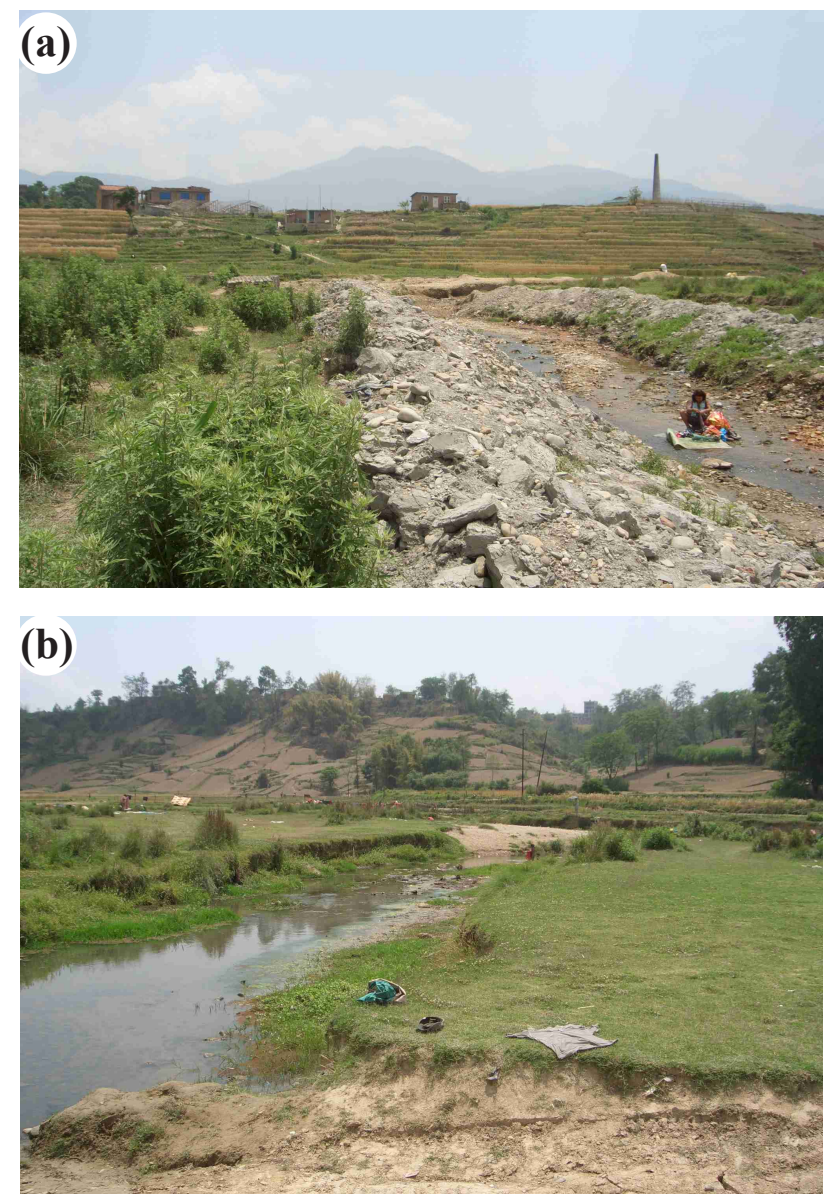

Fig. 5.14 (a) Transects HT-3 in the Harisidhi Segment, and (b) Upstream view from the transect HT-8 in the Harisidhi Segment.

frequently enchroached from builders. The riparian vegetation is very poor and frequently absent, but when present consists of only shrubs and herbs.

\section{DISCUSSIONS}

The four segments which have been surveyed indicate that they are moderately entrenched. The fifth order segments of the Nakhu River are relatively more entrenched than those of the Manahara River, but the fifth and sixth order segments of the Bishnumati River are even more entrenched (Table 6). Among the three rivers, W/D ratio of the Nakhu River is intermediate between high ratios of the Manahara River and the low of the Bishnumati River. Sinuousity, is highly variable, but the fourth order segment of the Nakhu River shows the least sinuosity. Remarkably, radius of curvature of the Nakhu River is highest among the rivers. Considering the slope, the fifth order segment of the Nakhu River shows the highest slopes among the rivers. The meander length and meander belt width of the Nakhu River exhibit low range while that of the Manahara and the Bishnumati Rivers show wide range. Considering D50 of the fifth order segments, all lie in sand-grade except for the upstream segment of the Nakhu River. In the latter, $\mathrm{D}_{50}$ of the fourth order segments is the coarsest because of existence of debris flow events and derivation of large sized gravel in this river. The variability of the above parameters among the rivers is attributed to river dynamics of the individual basin and supply of sediments from the source rocks. Compared to the Bishnumati and the Manahara River, the Nakhu River is more capable of carrying huge volume of sediments considering its competency. The fourth (Segment 4) and fifth (Segments 1,2 and 3) order segments of this river are aggrading in nature.

\section{CONCLUSIONS}

The preliminary assessment of the Kodku River as a part of the stability assessment was undertaken. The methodology was set up and given for complete study of river stability assessment. The river was characterized for its broad level geomorphic and hydrologic parameters. The river segments were then classified using Level I classification criteria, and then Level II classification criteria for more refinement of the Level I system.

The Kodku River is a fifth order stream, a remarkable southern tributary of the Manahara River. The Kodku River extends for about $15.86 \mathrm{~km}$ and its watershed covers an area of $35.67 \mathrm{sq}$. km.

The relative relief varies from extremely high to low. The relative relief diminishes with change of landforms from steep sloped bedrock terrain in the southern part of the watershed to the gentle sloped terrace landforms in the northern part of the watershed.

Drainage texture of the Kodku River watershed ranges from fine to very coarse. The fine drainage texture is localized to southern mountainous areas with bedrocks and steep slopes, whereas coarse drainage texture is located towards the mid to northern portion of the watershed where valley sediments with terraced landforms have developed. 
Considering the planform parameters, all the stream segments are sinuous $(\mathrm{K}=1.2)$ whereas the Arubot Segment is the highly meandering (1.7). Both meander wavelength $\left(\mathrm{L}_{\mathrm{m}}\right)$ and belt width $\left(\mathrm{W}_{\mathrm{blt}}\right)$ increase with increasing stream order. But the fifth segment shows the diminishing trend probably due to anthropogenic alteration of the river.

Five types of valleys have been distinguished and are I, II, IV, VI, and VIII type valleys. Based on valley type distribution, channel pattern, shape and channel slope, the individual stream segments of the main stem river covering two meander wavelengths, have been classified (Level I broad level classification) as 'B' type, 'C' type and 'Aa+' type streams. The ' $\mathrm{B}$ ' type streams are all located in the third order segment. Except the 'Aa+' type stream at the gorge near Jharuwarasi, all the fifth and fourth order stream segments of the main stem Kodku River belong to ' $C$ ' type streams.

Width/Depth ratio varying between 10.5 and 29.5 indicates laterally unstable channel segments. The bank height ratio (BHR), which also varies between 1.6 (Badikhel Segment) and 2.4 (Harisidhi Segment), indicates moderate incision and shows vertical instability of streams. The entrenchment ratio ranges from 1.7 to 7.1 and the Badikhel Segment is relatively more entrenched (1.7) while the Taukhel Segment is the least entrenched (7.1) among them. Since ER exceeds 1.6, the stream segments of the Kodku River are considered to have moderate to low entrenchment.

The bed material size analysis indicates that the median sizes of sediments of the Badikhel Segment are coarse pebble, whereas those for Taukhel Segment are silt/clay mixture. The median sizes of the Arubot Segment and the Thaiba Segment both belong to very coarse sand. The Harisidhi Segment possesses very fine pebbles as substrate material. Thus, the Kodku River is a gravelly mixed-load meandering river.

Level II classification distinguishes two-types of streams for the selected five stream segments. The Badikhel Segment is a 'B4c' type stream. The Taukhel Segment (fourth order segment) is a 'C6c' type stream. The fifth order segments such as the Arubot Segment, Thaiba Segment and the Harisidhi Segments all are classified as ' $\mathrm{C} 4 \mathrm{c}$ ' type streams.

The 'B4c' type stream is entrenched and somewhat laterally confiled by steep valley slopes and terrace landforms. It has tendency of vertical and lateral accretion. The 'C6c' type stream is a meandering stream with shallow channel and wide valley. The ' $\mathrm{C} 4 \mathrm{c}$ ' type streams have shallow and wide meandering channels with well developed flood plains and lateral bars and have tendency of lateral instabilities.

\section{ACKNOWLEDGEMENTS}

Authors are thankful to University Grant Commission (UGC) for providing a support for carrying out this study. Authors also thank Central Department of Geology for providing necessary facilities.

\section{REFERENCES}

DMG, 1998, Engineering and Environmental Geological Map of Kathmandu Valley, Department of Mines and Geology, Lainchaur, Kathmandu.

Horton, R.E., 1945. Erosional development of streams and the streams and their drainage basins: Hydrological approach to quantitative geomorphology. Bulletin of the Geological Society of America, Vol. 56, pp. 275-370.

Leopold, L.B., Wolman, M.G. and Miller, J.P., 1964. Fluvial processes in geomorphology. W. H. Freeman \& Co., San Fransisco, U.S.A., 522p.

Maharjan, L. and Dangol, V., 2007. Engineering hydrology of Kodku Khola Basin, Lalitpur, Nepal. Bull, Dept. Geol., Tribhuvan University, Kathmandu, Nepal, Vol. 10, 2007, pp. 107-116.

Maharjan, V. and Tamrakar, N.K., 2010. Morpho-hydraulic parameters and existing stability condition of the Nakhu River, southern Kathmandu, Central Nepal. Bull. Dept. Geol., Tribhuvan University, v. 13, pp. 1-12.

Rosgen, D.L., 1994. A classification of natural rivers, Cantenna, V. 22, pp. 169-199.

Rosgen, D. L. 1996. Applied River Morphology. Wildland Hydrology Books, Pagosa Springs, Colorado.

Saijo, K., Kimura, K., Dangol, G., Komatsabara, T., and Yagi, H., 1995. Active faults in southern Kathmandu basin, Central Nepal, Journal of Nepal Geological Society (Special issue), v. 11, pp. 217-224.

Sakai, H., 2001. The Kathmandu Basin: an archive of Himalayan uplift and past monsoon climate. Jour. Nepal. Geol. Soc., Special Issue, v. 25, pp. 1-8.

Shrestha, P. and Tamrakar, N.K., 2007. Streambank erodibility and lateral instability hazard in the Manahara River, Kathmandu basin, Nepal, Jour. Nepal Geol. Soc., v. 35, pp. 55-66.

Shrestha M. B., Tamrakar, N.K., and Miyazaki, T., 2008. Morphometry and sediment dynamics of the Churiya 
River area, Siwalik Range in Neoal. Boletin de geologia, v. 30, no. 2, pp. 35-48.

Stöcklin J. (1980), Geology of Kathmandu area and central Mahabharat range, Nepal Himalaya, HMG-UNDP, Mineral exploration project, Kathmandu Nepal.

Strahler, A.N., 1957. Quantitative analysis of watershed geometry. Trans-American Geophysical Union, v. 38, pp. 913-920.

Strahler, A.N., 1969. Physical Geography. 3rd edition, John Willey and Sons, Inc. New York.

Tamrakar, N.K., 2004, Disturbances and Instabilities in the Bishnumati River Corridor, Kathmandu Basin. The JUSAN (Japan University Students Association Nepal), v. 9, issue 16, pp. 7-18.

Tamrakar N.K and Bajracharya, R., 2009, Fluvial Environment and Existing Stability Condition of the Manahara River, Central Nepal, Journal of Nepal Geological Society, v. 39, pp. 45-58.

Tamrakar, N.K. and Bajracharya, R., 2012. Basinal and planform characteristics of the Kodku and the Godavari Rivers, Kathmandu Nepal. Bull. Dept. Geol., v. 15, pp. 15-22.

Wolman, M.G., 1954, A method of sampling coarse riverbed material. Trans. Am. Geophys. Union, v. 35, pp. 951-956.

Yagi, H., Maemoku, H., Ohtsuki, Y., Saijo, K., and Nakata, T., 2000. Recent activities faults distributed in and around Kathmandu Valley, Lower Himalayan Zone. In: Okumura, K., et al. (eds), Active faults Research for the New Millenium. Proceeding of the Hokudan Internalational Symposium and School on Active Faulting, pp. 557-560.

Yoshida, M. and Igarashi, Y., 1984. Neogene to quaternary lacustrine sediments in the Kathmandu Valley, Nepal, Journal of Nepal Geological Society, Special Issue, v. 4, pp. 73-100. 